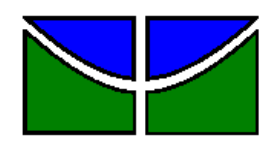

Universidade de Brasília

Faculdade de Economia, Administração, Contabilidade e Ciências da Informação e Documentação

Departamento de Administração

GEOVANI TEIXEIRA BARROSO

\title{
A RESPONSABILIDADE SOCIAL E SUA RELAÇÃO COM O NÍVEL DE COMPROMETIMENTO DOS FUNCIONÁRIOS DE UMA INSTITUIÇÃO FINANCEIRA NACIONAL: uma análise à luz do comportamento ético nas organizações
}


Universidade de Brasília

Faculdade de Economia, Administração, Contabilidade e Ciências da Informação e Documentação

GEOVANI TEIXEIRA BARROSO

\section{A RESPONSABILIDADE SOCIAL E SUA RELAÇÃO COM O NÍVEL DE COMPROMETIMENTO DOS FUNCIONÁRIOS DE UMA INSTITUIÇÃO FINANCEIRA NACIONAL: uma análise à luz do comportamento ético nas organizações}

Trabalho de conclusão de curso apresentado ao Departamento de Administração como requisito parcial à obtenção do título de Bacharel em Administração.

Professor Orientador: Dra. Mylene Pitsica Marques

Brasília - DF

Novembro / 2009 


\title{
A RESPONSABILIDADE SOCIAL E SUA RELAÇÃO COM O NÍVEL DE COMPROMETIMENTO DOS FUNCIONÁRIOS DE UMA INSTITUIÇÃO FINANCEIRA NACIONAL: uma análise à luz do comportamento ético nas organizações
}

\begin{abstract}
A Comissão Examinadora, abaixo identificada, aprova o Trabalho de Conclusão do Curso de Administração da Universidade de Brasília do (a) aluno (a)
\end{abstract}

\section{Geovani Teixeira Barroso}

Dra Mylene Pítsica Marques

Professor-Orientador

M.e Antônio Nascimento Junior Professor-Examinador
M. ${ }^{\text {a }}$ Priscila Maria de Sousa Dourado

Professor-Examinador 
Aos meus pais e a minha família, pela fidelíssima confiança em mim depositada e o incentivo que nunca me faltou $e$ a todas as pessoas que colaboraram de alguma forma com a realização deste trabalho. Com ternura, hei de lembrar-me de seus inefáveis esforços, sem os quais, talvez, eu não pudesse lograr êxito nesta auspiciosa jornada. 
Agradeço a Deus pelo seu mecenato divino, por intermédio do qual pude auferir recursos demasiado valiosos, como a dádiva da vida, a saúde e os talentos necessários para superar os mais diversos obstáculos.

Regozijo-me imensamente pelo apoio que recebi das professoras Mylene Pítsica Marques e Juliana Barreiros Porto, ambas do Departamento de Administração da Universidade de Brasília.

Gostaria, por fim, de mandar um salve para Polyana Cabral da Rocha e Maurício Teixeira de Sousa, pessoas cuja solicitude incondicional se mostrou decisiva ao longo das várias etapas deste trabalho. 
"O homem das civilizações tardias e de lucidez declinante será, a grosso modo, um indivíduo mais frágil” (Nietzsche) 


\section{RESUMO}

O tema Responsabilidade Social vem ganhando, nos últimos anos, espaço cada vez maior na agenda de organizações, que influenciadas pelo dinamismo dos valores que caracterizam a sociedade moderna, procuram amparar seus negócios no comportamento ético e no respeito aos interesses dos diversos públicos que com elas interagem. Vários estudos sinalizam a existência de um elo entre conduta socialmente responsável e aquisição de vantagens competitivas pelas empresas. Outros atestam, no mesmo caminho, que a Responsabilidade Social pode ser utilizada como um instrumento de marketing interno e externo para as organizações. Sendo assim, realizou-se uma pesquisa descritiva envolvendo quarenta e nove funcionários do departamento de tributos de uma grande instituição financeira nacional com o propósito de se investigar a relação entre ações internas de Responsabilidade Social e comprometimento organizacional afetivo. Os resultados indicam uma correlação positiva entre estas variáveis, o que, todavia, não pode ser afirmado de forma conclusiva e peremptória devido a algumas limitações deste trabalho.
1. Responsabilidade
2. Comportamento Ético
3. Comprometimento
Social
Organizacional 


\section{SUMÁRIO}

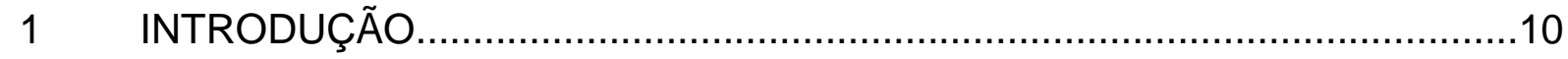

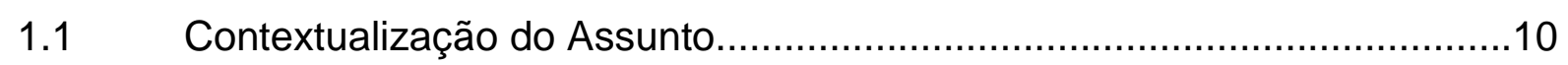

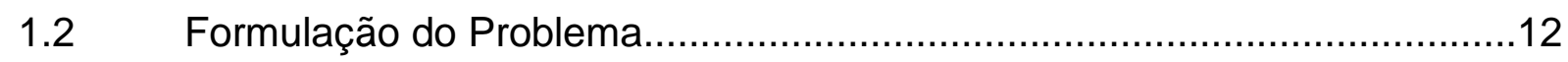

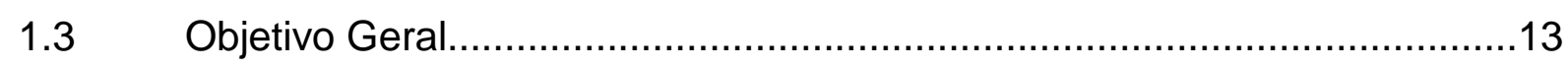

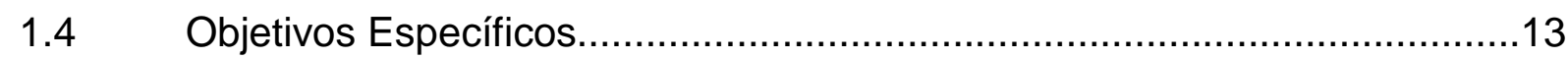

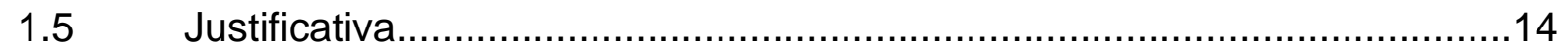

$1.6 \quad$ Métodos e Técnicas de Pesquisa..........................................................

1.7 Estrutura e Organização da Monografia................................................15

2. REFERENCIAL TEÓRICO......................................................................17

2.1 Conceitos Preliminares sobre Responsabilidade Social..........................17

$2.2 \quad$ Justificando a Responsabilidade Social..............................................19

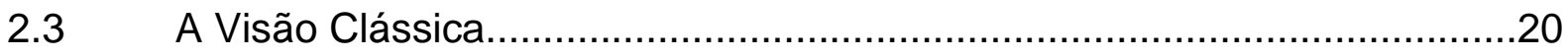

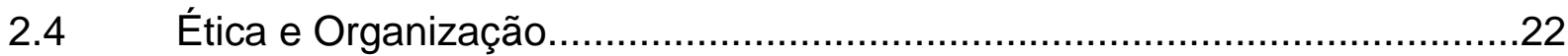

2.5 Marketing Social e Ações Socialmente Responsáveis...............................24

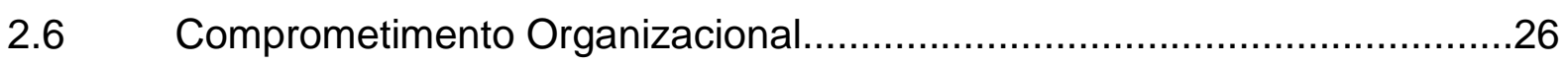

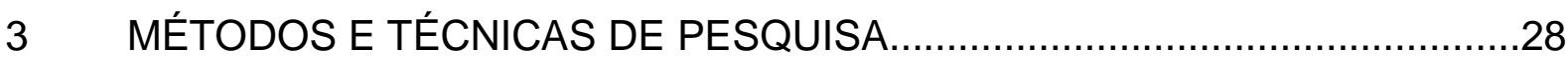

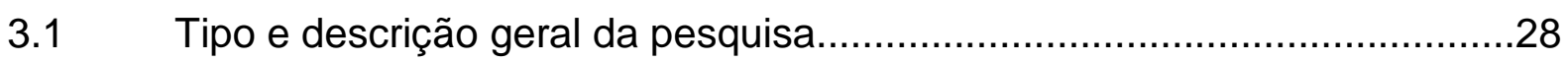

3.2 Caracterização da Organização e do Setor.................................................

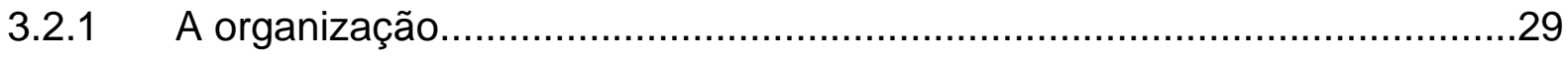

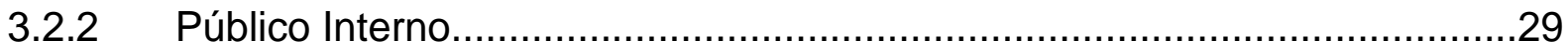

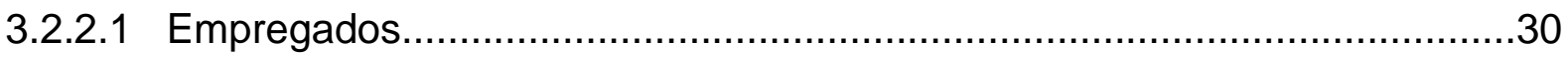

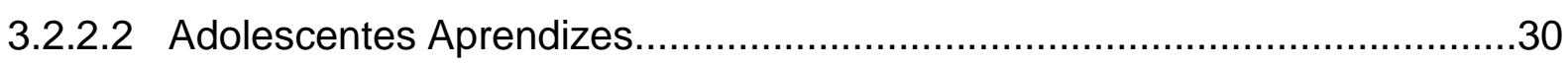

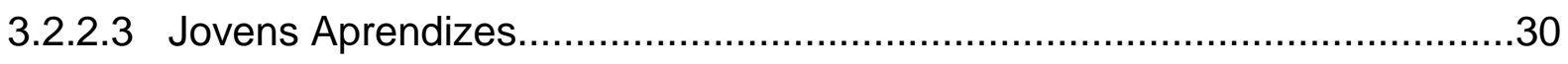

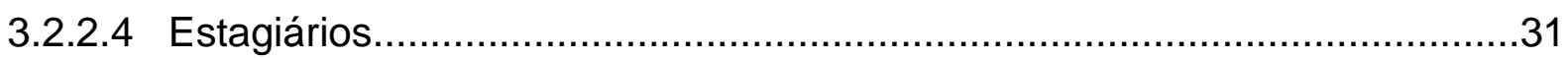

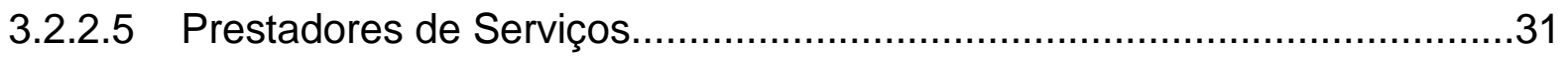

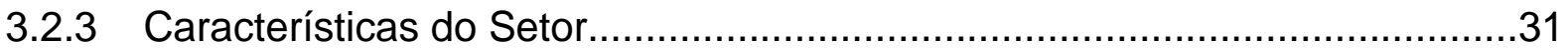

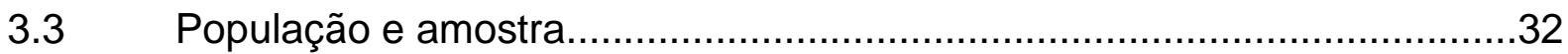

3.4 Caracterização dos Instrumentos de Pesquisa..........................................32

3.5 Procedimentos de Coleta e de Análise de Dados.........................................35

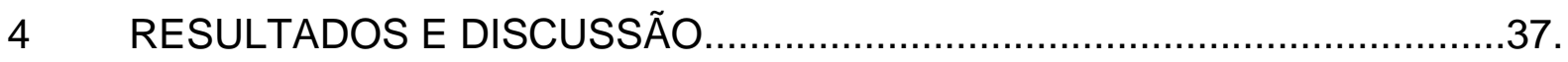

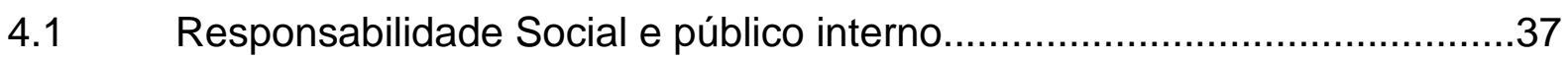

4.1.2 Perfil dos colaboradores..................................................................... 


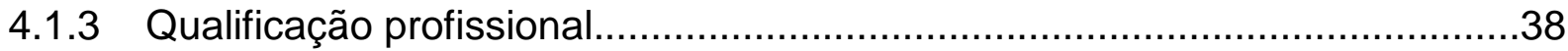

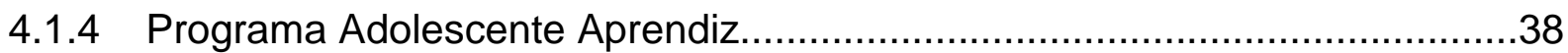

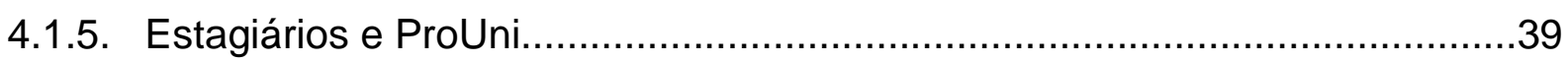

4.1.6 Direitos trabalhistas e relações sindicais...................................................

4.1.7 Participação dos resultados.................................................................

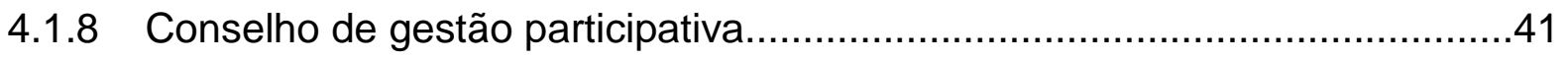

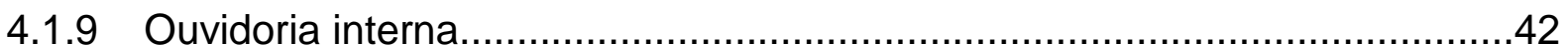

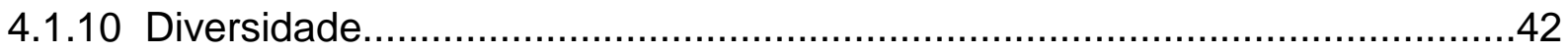

4.1.11 Ações de conscientização sobre a diversidade............................................4

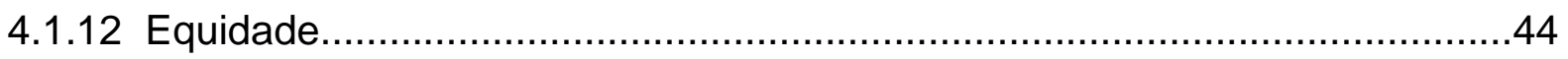

4.1.13 Segurança, saúde e condições de trabalho..............................................45

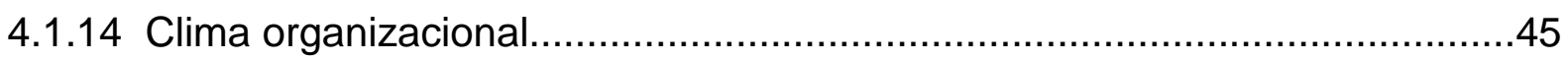

4.2 Sobre as ações de Responsabilidade Social internas................................46

4.3 Porcentagem, medidas de tendência central, posição e dispersão de

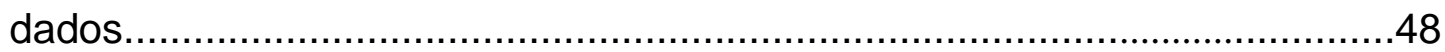

4.4 Aplicação, apuração dos resultados e interpretação da ECOA....................53

4.5 Aplicação, apuração dos resultados e interpretação da EPCEO.................53

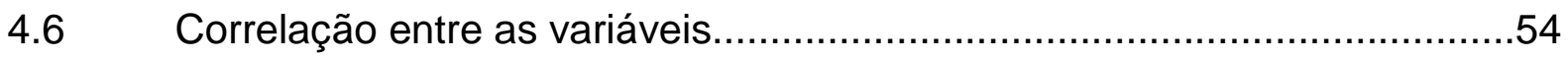

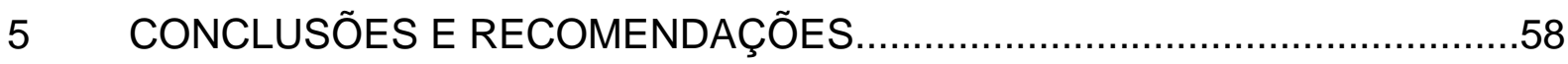

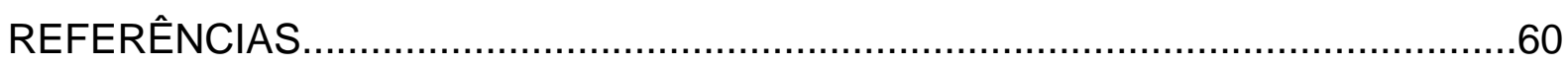

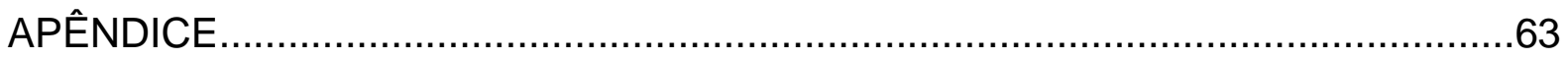

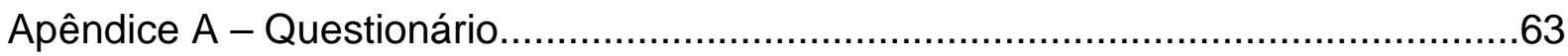

Apêndice B - Roteiro de Entrevista Semi-Estruturada..........................................67

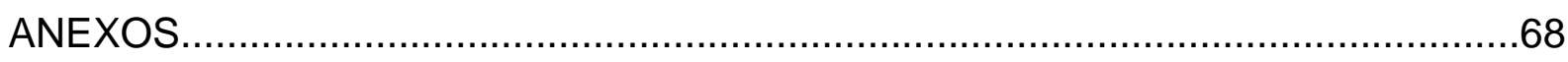

Anexo A - Escala de comprometimento organizacional afetivo - ECOA....................68

Anexo B - EPCEO

Anexo C - Valores para o coeficiente de correlação de Spearman...........................72 


\section{INTRODUÇÃO}

\subsection{Contextualização do Assunto}

O amplo debate sobre o papel das empresas na sociedade moderna investe a Responsabilidade Social como um assunto que, atualmente, demanda especial atenção e comprometimento da parte de pesquisadores e estudiosos das organizações e de administradores e executivos. Observa-se uma tendência de redefinição dos modelos de negócios das empresas em face das profundas transformações de ordem econômica, social e política pelas quais o planeta vem passando nas últimas décadas (PINTO; LARA, 2004). Hobsbawn (2003) discorre que, desde a Revolução Industrial, a economia do mundo vem apresentando um acelerado progresso técnico, cujo crescimento, embora seja irregular, mostra-se contínuo. Além disso, segundo o autor (HOBSBAWN, 2003), percebe-se uma divisão internacional do trabalho cada vez mais complexa e uma grande rede de intercâmbio que liga todas as partes da economia mundial ao sistema global. Tais fenômenos sinalizam uma nova realidade, que:

estaria forçando as empresas a investir em outros atributos, além de preço e qualidade, como confiabilidade, serviço de pós-venda, produtos ambientalmente corretos e relacionamento ético das empresas com seus consumidores, fornecedores e varejistas, além da valorização de práticas ligadas à segurança de seus funcionários e à preservação do meio ambiente (PINTO; LARA, 2004, p.49, grifo nosso).

A temática da Responsabilidade Social se desenvolve, ainda, em meio a um cenário de desconfiança quanto à legitimidade do Estado e de dúvida quanto à capacidade deste de propor um grande projeto que garanta o desenvolvimento econômico e social (ENRIQUEZ, 1997). Eis que ocorre, neste contexto, um processo de reordenação das forças sociais que, segundo Coutinho e Macedo-Soares (2002), direciona os esforços das empresas para a adoção de uma postura socialmente responsável na condução de seus negócios. Este despertar da consciência social das empresas não se reflete em indicadores de desempenho estritamente econômicos, mas retrata a perspectiva de sucesso empresarial sob a ótica de um 
cenário que exige, também, resultados sociais e ambientais (COUTINHO; MACEDOSOARES, 2002; RIBEIRO, 2003). O termo "Responsabilidade Social" se associa, portanto, a decisões de negócios que se baseiam, de acordo com Machado Filho (2006), em valores éticos, os quais incorporam, por seu turno, as dimensões legais e o respeito pelas pessoas, comunidades e meio ambiente.

Pinto e Lara (2004) encontram na Responsabilidade Social uma forma de as organizações buscarem o desenvolvimento de vantagens competitivas, que viabilizem suas atividades e as aproximem de seus públicos interno e externo. Coutinho e Macedo-Soares (2002) corroboram esta tese ao afirmar que a dimensão estratégica da Responsabilidade Social reflete um ambiente de trabalho mais motivador e eficiente, contribui para a construção de uma imagem institucional positiva e solidifica as interações na cadeia de relacionamentos organizacional.

A ética constitui um dos principais pilares da Responsabilidade Social Empresarial e pode ser conceituada em termos de um padrão moral não governado por lei que focaliza a análise das conseqüências das ações humanas por meio da emissão de juízos de valor (MACHADO FILHO, 2006). Traduz-se, na realidade organizacional, em um código de princípios e padrões que, segundo Pinto e Lara (2004, p.51), “definem a conduta aceitável determinada pelo público, órgãos regulamentadores, grupos privados interessados, concorrentes e a própria organização". Para Enriquez (1997), os desafios éticos impostos às organizações modernas culminam na busca pela transmissão de uma imagem virtuosa, suscetível de causar processos de idealização entre seus colaboradores e, por conseguinte, angariar, legitimamente, os esforços e o comprometimento destes na consecução dos objetivos organizacionais. A insistência sobre a Responsabilidade Social seria, consoante a lógica do comportamento ético, a prova da consideração da empresa para com o homem em todas as suas dimensões (ENRIQUEZ, 1997).

Desta forma, Machado Filho observa (2006) que a atividade empresarial possui, integrada às suas dimensões econômica e legal, uma dimensão ética, que revela a atribuição de se resguardarem os direitos de todos os agentes afetados pela empresa, promovendo o bem dos mesmos. Identificam-se os funcionários de uma empresa como parte integrante deste grupo, uma vez que "[eles] têm os seus empregos e, em grande medida, sua vida pessoal dependentes da organização. Em troca de seu trabalho, esperam da organização salários, segurança, benefícios, 
entre outros retornos" (MACHADO FILHO, 2006, p.9). Ademais, na esteira da crescente preocupação do mundo com os Direitos Humanos e do aprimoramento contínuo das leis trabalhistas, o capital humano emerge com um dos principais alicerces das organizações. Neste contexto, Ribeiro (2003) assinala que a implementação de práticas gerenciais de vanguarda exige da empresa esforços no sentido de promover maior participação dos funcionários no processo decisório e nos lucros que decorrem de aumentos de produtividade.

Argumenta-se, por fim, que, na atual realidade de profundas transformações sociais, econômicas e políticas, algumas idéias que inspiram o posicionamento socialmente responsável das empresas perante seus funcionários podem possuir uma fundamentação predominantemente ética (que será utilizada neste trabalho) não obstante a importância de outros enfoques que também orbitam em torno do tema - Coutinho e Macedo-Soares (2002) chamam atenção para a existência de, pelo menos, mais três faces da Responsabilidade Social, a saber: econômica, que orienta os negócios da empresa para o lucro; legal, que subordina as ações organizacionais à obediência das leis; e filantrópica, que prevê o engajamento estratégico da organização em causas humanistas. A partir destas considerações, abrem-se as cortinas para o presente trabalho, cujo problema de pesquisa será apresentado a seguir.

\subsection{Formulação do Problema}

A organização objeto de estudo nesta pesquisa foi fundada há quase cento e cinqüenta anos, é uma das maiores instituições financeiras do Brasil e conta com um público interno que soma cerca de noventa e oito mil colaboradores, entre empregados concursados, prestadores de serviços, adolescentes aprendizes e estagiários. Abraçando a Responsabilidade Social em seu planejamento estratégico, esta organização, hoje, no que concerne aos interesses de seus funcionários, procura sempre pautar suas ações no diálogo, no respeito ao indivíduo e no estímulo permanente ao pleno aproveitamento do potencial do seu público interno. Suas iniciativas no campo da Responsabilidade Social revelam, desta forma, a 
primazia pela ética como valor que norteia a busca pelo aprimoramento constante do relacionamento da empresa com sua força de trabalho.

Mas qual a relação entre o nível de comprometimento afetivo dos funcionários desta organização e as ações de Responsabilidade Social que ela desenvolve, especialmente, para o seu público interno? Neste trabalho, procurou-se responder a esta pergunta em etapas. A primeira delas envolveu a formulação de um "objetivo geral", capaz de definir aquilo que será feito para dar resposta à pergunta de pesquisa. A etapa seguinte constituiu na listagem dos "objetivos específicos" do trabalho, que figuram na pesquisa como um detalhamento do objetivo geral.

A pesquisa foi descritiva, com abordagem fundamentalmente quantitativa, e se valeu de dados secundários e primários para a solução do problema. Contou, ainda, com o apoio de questionários e de entrevista pessoal semi-estruturada como instrumentos de apoio a sua realização e com a análise de dados representada pelo uso da ferramenta SPSS e pela aplicação de conceitos oriundos da estatística descritiva.

\subsection{Objetivo Geral}

Relacionar o comprometimento afetivo dos funcionários da instituição financeira ao modo como eles percebem as ações de Responsabilidade Social que esta direciona, especificamente, para o seu público interno, à luz do comportamento ético organizacional.

\subsection{Objetivos Específicos}

a) Listar as atuais ações de Responsabilidade Social da instituição financeira voltadas, especificamente, para o seu público interno;

b) Descrever a percepção dos funcionários sobre o comportamento organizacional ético da instituição financeira, o qual inspira o desenvolvimento dessas ações; 
c) Mensurar o nível de comprometimento organizacional afetivo na instituição financeira.

\subsection{JUSTIFICATIVA}

O presente trabalho tem por pretensão refletir o crescente interesse de pesquisas sobre os mecanismos por intermédio dos quais ações socialmente responsáveis beneficiam as organizações. O termo Responsabilidade Social não está definitivamente consolidado; suscita, portanto, uma série de interpretações e representa uma transformação na concepção da empresa e de seu papel na sociedade (PINTO; LARA, 2004, p.50). Entende-se, ainda, que, hoje, muitas campanhas de mudança social conseguem pouco resultado, fato que pode engendrar uma descrença generalizada em sua eficácia (KOTLER, 1993). Isto se revela na constatação de que, embora o exercício da Responsabilidade Social seja crescente, seus resultados nas organizações possuem pouca comprovação empírica, uma vez que os estudos que tratam do tema têm-se mostrado, muitas vezes, contraditórios e inconclusivos (MACHADO FILHO, 2006). Logo, este projeto de pesquisa se torna importante na medida em que se propõe a lançar algumas luzes sobre o conceito de Responsabilidade Social, ainda obscuro para muitas pessoas e freqüentemente assimilado de modo simplista por tantas outras. Pretende-se enfatizar, nas sessões seguintes, o argumento de que uma análise aprimorada e translúcida da Responsabilidade Social contribui para preencher as lacunas deixadas por esta literatura ainda incipiente. Além disso, em um mercado de trabalho onde a carreira no serviço público se revela cada vez mais sedutora, as instituições financeiras se deparam com o desafio de estabelecer formas de estreitar os laços que as unem aos seus funcionários, sendo o comprometimento organizacional uma delas.

\subsection{Métodos e Técnicas de Pesquisa}


Foram utilizados questionários e entrevista pessoal semi-estruturada para a consecução dos objetivos deste trabalho. Foram obtidos, por intermédio de pesquisa documental, dados secundários referentes às práticas de Responsabilidade Social do banco que se voltam para o seu público interno, em relatórios organizacionais de domínio público referentes ao exercício do ano de 2008. Os questionários foram distribuídos por uma funcionária na Gerência de Tributos da empresa. Já a entrevista pessoal foi feita com um dos funcionários responsáveis pela coordenação das ações de Responsabilidade Social da instituição financeira, o qual se encontra alocado na Gerência Nacional de Responsabilidade Social do banco. Os dados obtidos nos questionários foram tratados com a ferramenta SPSS, servindo alguns conceitos da estatística descritiva como instrumentos de apoio. Ao final, analisou-se a correlação existente entre as variáveis Responsabilidade Social e Comprometimento Organizacional Afetivo.

\subsection{Estrutura e Organização da Monografia}

No referencial teórico, abordam-se, em um primeiro momento, noções preliminares sobre Responsabilidade Social, situando-as ao contexto em que se desenvolveram as teorias sobre o assunto no século $X X$ e às implicações do tema no mundo contemporâneo. Ainda nesta fase, citam-se algumas justificativas para a adoção de práticas socialmente responsáveis nas organizações, contrapondo-as, em seguida, à visão clássica de Responsabilidade Social, cuja essência é apresentada em linhas gerais. Em um segundo momento, a ética é exposta como um importante fator de sucesso nos negócios, porquanto congrega, de forma eficaz, as expectativas da sociedade às ações das empresas. Também se discute, no âmbito do marketing social, em que medida a adoção de práticas socialmente responsáveis pode influenciar o comportamento dos funcionários de uma organização. Por fim, são elencadas três abordagens unidimensionais de comprometimento organizacional, elegendo-se, entre elas, o enfoque afetivo como parâmetro para esta monografia.

No capítulo de Métodos e Técnicas de Pesquisa, é descrito o modo como a esta foi conduzida e operacionalizada. Assim, destaca-se que a presente pesquisa 
foi descritiva com abordagem fundamentalmente quantitativa e que seus dados se originaram de análise documental e de coleta estruturada. Nesta etapa, também são apresentadas as principais características da organização objeto de estudo neste trabalho, bem como critérios relacionados ao processo para definição da amostra e informações sobre o tamanho e a representatividade desta. Em seguida se descrevem mais minuciosamente os elementos que caracterizam os instrumentos de pesquisa adotados e os procedimentos de coleta e análise de dados.

$\mathrm{Na}$ seção seguinte, intitulada "Resultados e Discussão", apresentam-se informações referentes aos fenômenos observados ao longo da pesquisa. No presente trabalho, são mostradas a porcentagem e a freqüência com que ocorreram alguns casos, bem como medidas de tendência central e de dispersão para as variáveis intervalares. Em seguida, estuda-se a correlação entre ações de Responsabilidade Social interna e comprometimento organizacional afetivo por intermédio do coeficiente de correlação de Spearman, constatando-se, ao final, a existência de correlação positiva entre as mesmas.

Por fim, acrescentam-se, na conclusão, conhecimentos e informações novas sobre o que se escreveu ao longo do trabalho no bojo da reflexão subjacente aos limites e à importância do assunto estudado. 


\section{REFERENCIAL TEÓRICO}

\subsection{Conceitos Preliminares sobre Responsabilidade Social}

A trajetória das teorias que discorrem acerca da Responsabilidade Social tem sua origem na década de 1950, quando se percebem, ainda que de modo incipiente, mudanças nos valores da sociedade introduzidas pelos avanços tecnológicos e pelo grande crescimento econômico observados no período (TENÓRIO, 2004). Hobsbawn (2003) destaca que, nos anos ulteriores à Segunda Guerra Mundial, o modelo de produção de Henri Ford se espalhou para indústrias do outro lado do oceano, ao passo que alguns bens e serviços de luxo, antes restritos a minorias, passaram a ser produzidos, naquela época, para um mercado de massa. Para o autor (HOBSBAWN, 2003), o compromisso político de governos com o pleno emprego e com a seguridade social e previdenciária, pregado pela doutrina econômica keynesiana, constitui um dos principais sustentáculos desta expansão do mercado consumidor e de vendas. Ashley (2005) acrescenta que a essência do laço de compromisso firmado, nesta época, entre a sociedade e as empresas reside na intervenção do Estado como forma de buscar a justiça social.

Assim, a partir da segunda metade do século $X X$, as organizações, que, até então, exerciam seu papel social apenas em termos da maximização dos lucros, geração de empregos e pagamento de impostos, começam a considerar os anseios da sociedade e a incluir as expectativas de outros agentes, além de empregados, acionistas e governo, em seus planos de negócios (TENÓRIO, 2004). Esta tendência, no entanto, se desdobra, segundo Ashley (2005), em meio ao triunfo do neoliberalismo, no final do século $X X$, sobre as barreiras políticas, jurídicas e culturais impostas pelo aparelho estatal ao livre mercado. O ideário neoliberal, que preconiza a submissão das mais diversas relações sociais aos condicionamentos e disciplina de mercado, abriga-se sob a insígnia da globalização no mundo moderno e eleva o movimento em prol da Responsabilidade Social a uma forma de contenção do ímpeto pelo lucro individual socialmente destrutivo (ASHLEY, 2005). McIntosh et al. (2001, p.46) consideram que "o papel do governo é resumido ao de juiz, estabelecendo normas, originando legislações e trabalhando como um facilitador em 
vez de um fornecedor". No mundo globalizado, atribui-se aos negócios, enquanto forca motriz da sociedade, a tarefa de zelar pelos direitos humanos, combater a corrupção, distribuir a riqueza de forma mais justa e enfrentar questões ambientais (MCINTOSH et al., 2001).

É neste contexto que as teorias sobre Responsabilidade Social, cuja produção se acentua, de acordo com Tenório (2004), a partir da década de 1970, passam a abordar em seus cânones questões outrora relegadas pelas empresas, como comportamento ético e preservação do meio ambiente - esta última, movida pela familiar conotação quase política que se atribui, nos dias de hoje, ao termo "ecologia" (HOBSBAWN, 2003). Tachizawa (2008, p.53) enfatiza que "os novos tempos caracterizam-se por uma rígida postura dos clientes, voltada à expectativa de interagir com organizações que sejam éticas, com boa imagem institucional no mercado, e que atuem de forma ecologicamente sustentável".

Diante destas considerações, a Responsabilidade Social, neste trabalho, assume o conceito de relacionamento ético e responsável da empresa perante seus stakeholders - termo que remete aos diversos públicos que da organização reivindicam posses, direitos ou interesses (PINTO; LARA, 2004). Esta abordagem versa que o processo decisório organizacional transcende os aspectos antropocêntricos de apropriação da natureza pelo ser humano e de mercantilização das relações sociais para refletir o compromisso das organizações com a sociedade e o meio ambiente (ASHLEY, 2005).

Por outro lado, Coutinho e Macedo-Soares (2002) ressaltam que as organizações devem gerenciar seus relacionamentos tão somente com seus stakeholders, e não com a sociedade como um todo. Zylbersztajn (2002) partilha desta idéia ao enfatizar que atos cooperativos espontâneos entre as organizações e a sociedade devem se justificar, sempre, segundo uma ótica maximizadora de valor empresarial no longo prazo. Lima et al. (2005), preconizam que a Responsabilidade Social não deve ter seu escopo reduzido a medidas isoladas e meramente compensatórias perante as mazelas estruturais da sociedade. Zylbersztajn (2002) ressalta que o desejo de construir um ambiente empresarial cooperativo não deve, outrossim, mascarar estratégias oclusas, que se desdobram em prescrições normativas sem sentido crítico. Quando as ações sociais não são amparadas por controles internos adequados, as organizações podem enfrentar problemas de 
agência (ZYLBERSZTAJN, 2002), que se configuram, de acordo com Machado Filho (2006), como um conflito de interesses entre o acionista (principal) e o gestor (agente). Os diretores devem, na verdade, atuar como curadores de uma variedade de beneficiários, incluindo os acionistas (MCINTOSH et al., 2001).

\subsection{Justificando a Responsabilidade Social}

Há diversos fatores que ensejam uma postura socialmente responsável por parte das empresas. Tenório (2004) cita as legislações ambientais, a exigência dos consumidores, as reivindicações das comunidades afetadas pelas atividades industriais e a globalização como alguns dos fatores que exercem pressão externa sobre as empresas, cobrando destas a adoção de práticas que contribuam com a qualidade de vida da sociedade. Machado Filho (2006), por seu turno, acrescenta que, hoje, os indivíduos estão mais cônscios de seus direitos e deveres sociais e menos tolerantes a práticas abusivas e antiéticas. Ademais, na medida em que a globalização torna mais homogênea a diversidade cultural reinante entre os povos, a sobrevivência das organizações passa a depender de sua capacidade de se ajustar a padrões éticos cada vez mais rigorosos (ASHLEY, 2005).

O estímulo à Responsabilidade Social pode ocorrer, ainda, pela forma instrumental, que, segundo Tenório (2004), aponta para benefícios ou vantagens que as empresas podem obter por intermédio de suas ações sociais, como incentivo fiscal e fortalecimento da imagem. A empresa, inserida em um ambiente positivo de relacionamento social pode auferir retorno econômico pela valorização de sua marca (MACHADO FILHO, 2006). Para Mclntosh et al. (2001), em um cenário onde a mídia global afeta a imagem das organizações de maneira incisiva, manter a vigilância sobre a qualidade e a reputação torna-se um imperativo para o sucesso dos negócios.

A despeito da influência do governo e das pressões externas, Tenório (2004, p.35) afirma, que, "quando a responsabilidade social corporativa é motivada por questões de princípios, o risco de descontinuidade dos investimentos sociais é reduzido, pois esses valores estão inseridos na cultura da empresa". Para Ashley (2005), o fomento a práticas socialmente responsáveis, nas organizações, passa por 
uma reflexão prévia sobre ética empresarial, a fim de se construírem relações de confiança perenes e cristalizadas no ambiente social, econômico e ambiental.

Coutinho e Macedo-Soares (2002) identificam uma correlação positiva entre desempenho financeiro e atuação socialmente responsável, independente de qual das duas dimensões é tomada como variável dependente. Ashley (2005) afirma que a Responsabilidade Social, afeita a uma conduta ética e transparente, pode trazer consigo ganhos tangíveis para as organizações, a saber: a criação de um ambiente interno e externo mais favorável, o estímulo adicional para melhorias e inovações no processo de produção, maior acessibilidade ao capital, participação de mercado mais expressiva, entre outros.

Apesar dos argumentos em favor da Responsabilidade Social como prática extensiva a todos os stakeholders da organização, existem algumas abordagens de visão predominantemente clássica que a eles se contrapõem. Tal vertente será apresentada, em linhas gerais, no tópico que se segue.

\subsection{A Visão Clássica}

A Responsabilidade Social se refere, sob o prisma da visão clássica, à capacidade de a empresa satisfazer, em primeiro lugar, aos anseios por retorno financeiro de seus acionistas (MACHADO FILHO, 2006). Brigham e Houston (1999) declaram que este princípio deve nortear o processo decisório da maioria das sociedades anônimas - pessoas jurídicas autorizadas pelo Estado ou pelo Governo Federal e separadas e distintas de seus proprietários e administradores.

Tenório (2004) explica que, nesta concepção, as teorias que discorrem acerca da temática da Responsabilidade Social impregnam-se do forte teor liberal que caracteriza a sociedade industrial do início do século $X X$, onde, segundo Hobsbawn (2003), os valores da razão exerciam notável influência. Neste sentido, argumenta-se que os gestores não devem se ater a problemas de cunho social às expensas dos acionistas, a fim de se preservarem os direitos de propriedade destes últimos e de garantir a lógica de funcionamento do mercado, bem como sua capacidade de prover o bem-estar geral e alocar, eficientemente, os recursos 
organizacionais (MACHADO FILHO, 2006). Entende-se que, apenas ao Estado compete mitigar as distorções sociais, segundo uma vertente que, embora seja regida pelo egocentrismo, admite, ao mesmo tempo, a existência de instrumentos legais e éticos capazes de cercear o comportamento das organizações (MACHADO FILHO, 2006).

Mclntosh et al. (2001) chamam atenção para o caráter amoral que os negócios assumem quando balizados intrinsecamente pela geração de lucros e por obrigações econômicas e legais - que revelam um escopo limitado de Responsabilidade Social. Ademais, Ashley (2005, p.18) observa que "o Estado, apesar de ter a obrigação social de garantir ao cidadão o atendimento aos seus direitos constitucionais, não vem apresentando condições organizacionais, econômicas e políticas para resolver sozinho o problema [da sociedade]". Neste contexto, as organizações são chamadas a ponderar sobre seu papel social, partindo do pressuposto de que seu desempenho oscila em função do seu nível de relacionamento com a sociedade (TACHIZAWA, 2008).

Por outro lado, mesmo arautos da visão clássica parecem considerar, em algumas circunstâncias, os possíveis benefícios que práticas socialmente responsáveis podem oferecer. Brigham e Houston (1999), por exemplo, defendem o exercício da Responsabilidade Social quando as ações sociais mais significativas das empresas, em termos de custos, se revestem de um caráter obrigatório, normatizado pelo Estado. Os autores (BRIGHAM; HOUSTON, 1999) ressaltam, porém, que organizações que adotam, voluntária e unilateralmente, práticas de Responsabilidade Social tendem a ser menos competitivas, uma vez que possuem maior dificuldade de atrair capital. Sobre a falta de incentivos governamentais para a adoção de práticas socialmente responsáveis, Machado Filho (2006) ostenta a tese de que a lei propicia, nesse caso, um ambiente de negócios mais previsível, reforçando valores econômicos e éticos em um determinado arcabouço institucional.

Tanto a abordagem clássica de Responsabilidade Social - centrada na perspectiva de maximização da riqueza dos acionistas e de pagamento dos impostos pelas empresas a título de contribuição social - quanto a abordagem mais ampla e sistêmica - que considera os interesses dos diversos stakeholders da organização - parecem acenar para um aspecto em comum: a ética enquanto preceito balizador do comportamento organizacional (MACHADO FILHO, 2006). 


\section{4 Ética e Organização}

Moreira (2002, p.21) conceitua a ética como "o rol dos conceitos aplicáveis às ações humanas". Para Andreasen (2002), ela é produto de uma análise de padrões de conduta e de julgamento moral, que se coadunam, de acordo com Moreira (2002) para adequar a ação do homem ao conceito do bem comungado por uma sociedade, independentemente de quaisquer coações externas. A reflexão sobre a ética inspira uma cartilha de regras que devem fundamentar a conduta não somente das pessoas, mas, também, das organizações (ASHLEY, 2005). Logo, a ética organizacional pode ser vista como um conjunto de regras e princípios que norteiam o comportamento da organização no mundo dos negócios, ensejando a prática de ações socialmente responsáveis (SIQUEIRA, 2008).

Enriquez (1997) afirma que a sociedade enfrenta, nos dias de hoje, uma grave crise nos seus valores éticos, radicada na ascensão do individualismo no mundo moderno, da qual emana o apego às paixões mais aberrantes e a interesses divergentes. Esta realidade parece estar associada à lógica do "espírito capitalista" proposta por Weber (1987), onde os valores éticos se apresentam destituídos de uma conotação eudemonista. "O homem é dominado pela produção de dinheiro, pela aquisição encarada como finalidade última de sua vida" (WEBER, 1987, p.33). Aos indivíduos é imposta, assim, a busca pelo êxito pessoal e econômico como palavra de ordem, o que provoca a desigualdade social (ENRIQUEZ, 1997).

Por outro lado, não obstante a crise atual nos valores éticos, observam-se alguns focos de resistência do homem ao processo de instrumentalização - esforços que despertam anseios pela espontaneidade e por atos gratuitos (ENRIQUEZ, 1997). Neste cenário, as organizações são chamadas a se colocar a serviço do desenvolvimento social, aumentando a contribuição líquida dos negócios para o bem público e agindo conforme as expectativas dos agentes sociais (ANDREASEN, 2002; ENRIQUEZ, 1997; MACHADO FILHO, 2006).

De acordo com Moreira (2002), há diversos motivos que justificam uma postura ética das empresas, entre eles: a geração de lucros livre de contingências e intervenções futuras; a avaliação de desempenho mais transparente e fidedigna; e a cristalização dos laços de parceria mantidos pelas organizações. Deste modo, a 
ética pode ser considerada como um instrumento que agrega eficiência ao sistema capitalista, especialmente quando estimula atos reflexivos sobre as conseqüências das ações no ambiente organizacional (ASHLEY, 2005).

A relação entre ética e lei é outro assunto presente nos estudos de diversos autores. Moreira (2002), conceituando a lei como uma regra formal - dotada de sanção, atributividade e cumprimento obrigatório - afirma que as empresas têm o dever ético de obedecer à lei. Contudo, para ele (MOREIRA, 2002), direitos que não possuem respaldo na ética não devem ser exercidos pelas organizações - ainda que amparados pela legislação em vigor - ao passo que o descumprimento de leis inconstitucionais pelas mesmas deve se consubstanciar, apenas, mediante uma autorização do Poder Judiciário.

Machado Filho (2006) tece sua análise partindo da idéia de que as leis e a ética são parte do ambiente institucional de uma sociedade, refletindo, desta forma, limitações formais (normas e leis) e informais (crenças, códigos de conduta e costumes), que regem as relações políticas, econômicas e sociais em uma comunidade. Segundo o autor (MACHADO FILHO, 2006), nesta perspectiva, a ética, nos negócios, ocupa uma posição relativamente primaz sobre as leis, uma vez que se recomenda uma margem para o exercício de um poder discricionário, porém ético, pelo gestor, nas ocasiões em que a lei deixa lacunas.

De acordo com Enriquez (1997), a organização ética dissemina valores que incentivam seus membros a colaborar com a construção de um projeto da empresa, submetendo-os, para isso, a processos de recalque e repressão por eles legitimados.

A organização ética, ademais, possui a consciência de que não é responsável, apenas, pelo peso de suas ações presentes, que afetarão as gerações no futuro, mas, também, encarrega-se das heranças legadas do passado pelo modo como registra, aceita e deforma a História (ENRIQUEZ, 1997).

Ribeiro (2003) assevera que as empresas modernas são aquelas que concebem a administração enquanto um processo contínuo de resposta a um ambiente mutável, desempenhando, no cenário onde atuam, um papel social modulado pela ética na relação com seus stakeholders. 


\subsection{Marketing Social e Ações Socialmente Responsáveis}

Kotler e Roberto (1992) conceituam o marketing social como um esforço organizado, feito por um agente de mudança, visando convencer um determinado público-alvo a aceitar, modificar ou abandonar certas atitudes, práticas ou comportamentos. Defende-se que, embora o marketing social seja mais comumente associado ao governo e às entidades sem fins lucrativos - especialmente por conta dos objetivos altruístas que eles, de modo geral, perseguem - seus princípios podem, também, ser aplicados nas empresas com fins lucrativos, cujas decisões tem revelado, amiúde, uma preocupação crescente com problemas ligados à escassez de recursos naturais e á ética no relacionamento com o consumidor (ANDREASEN, 2002; TENÓRIO, 2004). Todavia, Andreasen (2002, p. 102) chama atenção para o fato de que o marketing social, nas organizações com fins lucrativos, "é um adjunto atraente que ajuda e empresa a desempenhar suas obrigações sociais, contribuindo, ao mesmo tempo, pelo menos em alguma medida, para sua lucratividade".

À vocação tipicamente mercadológica das estratégias tradicionais de marketing dos bancos e, de modo geral, das instituições financeiras modernas organizações que se inserem em um mercado que se caracteriza, sobretudo, pela forte concorrência, formação de conglomerados e desenvolvimento constante de novos produtos, serviços e processos - incorporam-se elementos do marketing social (ASHLEY, 2005; TOLEDO, 1978). Ashley (2005) explica esta tendência em face da necessidade que, hoje, as instituições financeiras possuem de manter uma imagem de cidadania perante seus diversos públicos, o que as leva, por exemplo, a criar produtos customizados ao segmento de mercado mais sensível aos problemas socioambientais.

Logo, os limites do domínio do marketing social, nas organizações com fins lucrativos, parece enquadrar a preocupação destas com a Responsabilidade Social, na medida em que elas objetivam satisfazer às várias demandas de seus diversos públicos, construindo, paralelamente, uma imagem positiva (MCINTOSH et al., 2001; PINTO; LARA, 2004;). Para Enriquez (1997), as ações sociais mobilizam a empresa a difundir sua perspectiva de futuro social, utilizando os meios adequados para realizá-lo e, por conseguinte, criando heróis positivos tais como ela os concebe 
previamente. A organização, em resposta ao desafio de perenidade que lhe é lançado, deve possuir, em seu interior, indivíduos capazes de se sacrificar voluntariamente por ela (ENRIQUEZ, 1997).

Assim, a adoção de práticas socialmente responsáveis pelas empresas, especialmente quando reforçada por uma eficaz estratégia de marketing social, pode, conforme Pinto e Lara (2004), ensejar o comprometimento do funcionário de várias maneiras. Em primeiro lugar, as organizações podem assumir a responsabilidade pelos anseios por um mundo mais justo e igualitário que seus funcionários, tomados coletiva, ou individualmente, podem ter. Além disso, práticas proativas de Responsabilidade Social podem incrementar a atratividade de uma empresa para candidatos a trabalho. Por fim, a empreitada de uma organização em negócios que se amparam em uma consistente política de desenvolvimento sustentável pode engendrar um senso de orgulho e afiliação por parte de seus funcionários (PINTO; LARA, 2004). Pesquisa de Pinto e Lara (2004) em empresas do varejo sugere que a Responsabilidade Social parece surtir mais efeitos positivos sobre o comprometimento dos funcionários do que, até mesmo, sobre a lealdade dos clientes à marca.

Para que tais efeitos sejam percebidos, o relacionamento ético das organizações com seus funcionários parece ser, também, uma condição de suma relevância. Moreira (2002), neste contexto, afirma que as empresas devem zelar pelos direitos de seus funcionários, quais sejam, a título de exemplo, os direitos de liberdade, privacidade e ampla defesa. Os princípios éticos aplicáveis ao relacionamento entre organizações e funcionários, segundo o autor (MOREIRA, 2002), devem refletir, ainda, entre outras coisas, a igualdade entre o corpo funcional, a motivação da vida além do ambiente de trabalho, o desenvolvimento de um sistema de valorização das competências profissionais e o amparo à saúde e à segurança do trabalhador. Ashley (2005) acrescenta a boa relação com os sindicatos, o pagamento de subsídios e benefícios e a existência de políticas para mulheres e minorias como outras facetas da Responsabilidade Social voltadas para o público interno.

Segundo Kotler e Roberto (1992), a efetividade das campanhas de mudança social depende da pesquisa e compreensão das necessidades, crenças, desejos e atitudes específicas do público alvo, bem como dos produtos sociais que estão 
sendo colocados no mercado. Porém, eles (KOTLER; ROBERTO, 1992) ressaltam que as pessoas, geralmente, procuram evitar informações perturbadoras, racionalizando-as ou, mesmo, resistindo a tais incursões em seus valores de alguma outra forma, o que faz com que as organizações lancem mão de disposições normativas a fim de promover novos comportamentos e valores, que as pessoas não adotariam voluntariamente.

\subsection{Comprometimento Organizacional}

A História da humanidade sempre esteve vinculada à Administração no sentido de desenvolvimento e aplicação de conhecimentos gerenciais pelo homem. Sinais marcantes da trajetória humana, como a construção das pirâmides egípcias ou a Revolução Industrial do século XVIII, não poderiam ser concebidos senão em virtude da qualidade de administrador inerente ao ser humano. No entanto, foi somente no início do século XX que a administração começou a se entender como ciência, incorporando teorias sistematicamente formuladas que pudessem colaborar com o desenvolvimento das organizações (CHIAVENATO, 1983). Neste contexto, um dos assuntos que mais vem sendo estudado pelos teóricos da Administração, ao longo dos últimos anos, são os aspectos que aludem ao trabalhador, sobretudo aqueles relacionados ao seu bem-estar e a sua saúde.

Morgan (1996) mostra que uma das principais contribuições da Escola de Relações Humanas foi mostrar que as atividades de trabalho não são influenciadas apenas pelo planejamento formal, mas também pela natureza dos seres humanos. Em linhas gerais, tal afirmativa parece traduzir, entre outras coisas, a importância que as organizações modernas têm atribuído aos aspectos que impactam no comprometimento de seus colaboradores internos. Neste sentido, Dessler (2003, p.12) afirma:

construir o comprometimento dos funcionários - aliando as metas dos empregadores e dos funcionários de modo que estes queiram fazer seu trabalho como se fossem os donos das empresas - leva a um esforço multifacetado no qual o $\mathrm{RH}$ desempenha um papel central. 
Pinto e Lara (2004) defendem que, embora haja múltiplas abordagens de comprometimento organizacional, elas parecem apontar para, pelo menos, três domínios gerais em comum, a saber: ligações afetivas do funcionário com a organização; custos percebidos pelo mesmo ao abandoná-la; e existência de disposições normativas que 0 obrigam a permanecer nela. Trata-se, respectivamente, dos enfoques afetivo, instrumental e normativo, que, na última década, predominaram no estudo do comprometimento organizacional (MEDEIROS et al., 2003; PINTO; LARA, 2004). De acordo com Pinto e Lara (2004), um empregado pode experimentar os comprometimentos normativo, instrumental ou afetivo em graus diferentes.

No enfoque normativo, a aceitação de valores e objetivos organizacionais acaba por exercer controle sobre as ações dos indivíduos e seu senso de dever, caracterizando um estado onde prevalece a influência da própria cultura da empresa e o foco na criação e aprimoramento de mecanismos de controles, tais como regulamentos e normas (MEDEIROS et al., 2003).

O enfoque instrumental, por sua vez, relaciona-se, segundo Pinto e Lara (2004, p. 53), a um "apego psicológico que reflete o grau em que o indivíduo se sente prisioneiro de um lugar pelos altos custos associados a abandoná-lo". Deste modo, Medeiros et al., (2003) mencionam que o comprometimento instrumental estimula os indivíduos a refletir, constantemente, sobre aspectos que melhor atendam a seus propósitos, como investimentos profissionais já realizados por eles na organização e a disponibilidade de planos de aposentadoria. Logo, de acordo com esta abordagem, vínculos fortes parecem emergir quando as organizações atendem às necessidades e expectativas trazidas pelo trabalhador.

Por fim, o enfoque afetivo, que será utilizado no presente trabalho, concebe o comprometimento como algo que vai muito além de uma postura de lealdade passiva para com a organização. Trata-se, pois, de um relacionamento ativo, em que o indivíduo, buscando o seu bem-estar, dispõe-se a exercer, voluntariamente, esforço considerável em benefício da organização, a partir de um forte apego às crenças e valores organizacionais e de um grande desejo de se manter membro fiel da organização, direcionando seus esforços espontaneamente em favor da mesma (MEDEIROS et al., 2003; SIQUEIRA et. al., 2008). 


\section{MÉTODOS E TÉCNICAS DE PESQUISA}

\subsection{Tipo e descrição geral da pesquisa}

Partindo da idéia de que a metodologia é a ciência que estuda os métodos de investigação e a apresentação de resultados científicos (GONÇALVES; MEIRELLES, 2004), esta pesquisa se desdobrou nos aspectos apresentados a seguir.

A pesquisa foi descritiva, uma vez que parte da formulação prévia de uma hipótese específica e de uma declaração precisa do problema, a fim de descrever as características do fenômeno objeto de estudo (GONÇALVES; MEIRELLES, 2004; MALHOTRA, 2005). De acordo com Gil (1999, p.44), "as pesquisas deste tipo [descritivas] têm como objetivo primordial a descrição das características de determinada população ou fenômeno ou o estabelecimento de relações entre variáveis".

A hipótese alternativa $(\mathrm{H} 1)$ - em cujo enunciado reside, segundo Gonçalves e Meirelles (2004), a solução desejada do problema - foi a seguinte: as ações de Responsabilidade Social voltadas para o público interno da instituição financeira funcionam como mecanismo indutor de comprometimento afetivo entre os funcionários desta organização. Sua contraparte, a chamada hipótese nula $(\mathrm{H} 0)$, constitui a sentença negativa de $\mathrm{H} 1$, no escopo de um modelo estritamente maniqueísta (GONÇALVES; MEIRELLES, 2004).

A abordagem da pesquisa foi, fundamentalmente, quantitativa, que, de acordo com Richardson (1999, p. 70), "caracteriza-se pelo emprego de quantificação tanto nas modalidades de coleta de informações, quanto no tratamento delas por meio de técnicas estatísticas [...]". Este enfoque, ao se desdobrar em uma precisa linguagem matemática, pode dirimir os vieses interpretativistas ambíguos, os quais resultam de modelos menos rigorosos quanto à conceituação e à operacionalização (GONÇALVES; MEIRELLES, 2004).

Foram usados dados secundários, entendidos, de acordo com Malhotra (2005), como aqueles já existentes e disponíveis, em alguma fonte, e que servem de 
suporte no cumprimento de etapas importantes para a solução do problema de pesquisa. Assim, de relatórios de domínio público do banco que contemplam o exercício do ano de 2008 foram extraídos dados referentes a quais práticas de Responsabilidade Social se voltaram, especialmente, para o público interno da organização, no período. No entanto, a criação de dados primários, que, para Malhotra (2005), são aqueles gerados pelo próprio pesquisador com a finalidade específica de solucionar o problema em pauta, também constou da agenda deste trabalho.

O desenho da pesquisa, por seu turno, foi transversal. Em outras palavras, realizou-se toda a pesquisa de forma episódica uma vez, em tempo previamente determinado (GONÇALVES; MEIRELES, 2004).

\subsection{Caracterização da Organização e do Setor}

\subsubsection{A organização}

A empresa onde se realizou a pesquisa é uma instituição financeira nacional fundada no ano de 1861. Como agente do governo federal, presta uma vasta gama de serviços a cerca de quarenta e sete milhões de correntistas e poupadores. A organização encerrou o ano de 2008 com um lucro líquido de $R \$ 3,9$ bilhões, justificado, especialmente, pela expansão do crédito. A empresa possui sede em Brasília (DF) e se subordina às decisões e à disciplina normativa do Ministério da Fazenda. Ademais, seu desempenho é acompanhado e fiscalizado pelo Banco Central do Brasil - BACEN.

\subsubsection{Público Interno}

A instituição financeira utiliza o termo "público interno" para se referir aos seus funcionários como um todo, os quais se encontram segmentados em grupos, de acordo com as peculiaridades descritas a seguir. 


\subsubsection{Empregados}

A aprovação em concurso público é a porta de acesso ao quadro permanente de colaboradores do banco. A classificação obtida na prova seletiva determina a ordem de convocação para assumir os cargos de carreira administrativa ou profissional. Para consumar sua admissão, o candidato tem de efetivar exames médicos e comprovar que preenche todos os requisitos previstos no edital de concurso público.

\subsubsection{Adolescentes Aprendizes}

Categoria criada em 2003 para designar os colaboradores admitidos por meio de Programa Adolescente Aprendiz, desenvolvido em parceria com entidades assistenciais com vistas a oferecer formação técnico-profissional a jovens de 15 a 17 anos e 11 meses. Em seu período na empresa, o adolescente recebe orientação educacional e profissional especializada. A iniciativa tem como público-alvo as populações de baixa renda, atendendo inclusive a comunidades indígenas e quilombolas, graças à capilaridade territorial da organização. A prioridade é a contratação de adolescentes oriundos de famílias beneficiadas pelos programas de inclusão social do governo federal.

\subsubsection{Jovens Aprendizes}

Como ampliação de seu programa de aprendizagem, a instituição financeira concebeu esta categoria de colaboradores no intuito de incentivar a inserção de jovens de 18 a 24 anos no mercado de trabalho - não há limite etário para portadores de deficiência física. As tarefas atribuídas ao jovem aprendiz envolvem um grau mais elevado de responsabilidades em relação àquelas desempenhadas pelo adolescente aprendiz. 


\subsubsection{Estagiários}

Outra via de ingresso no mercado de trabalho está nas vagas de estágio. Para se candidatar a estagiário da empresa, o jovem deve cursar o Ensino Médio ou Ensino Superior. Comprovantes de matricula e de freqüência em seus cursos, em escolas públicas ou particulares, são pré-requisitos para a admissão.

Agências bancárias e postos de serviços oferecem o primeiro contato com o mundo profissional aos jovens alunos de nível médio. Por sua vez, quem está ou já superou $05^{\circ}$ semestre do curso universitário pode atuar nas unidades administrativas da instituição financeira.

\subsubsection{Prestadores de Serviços}

São incluídos como prestadores de serviços os colaboradores de empresas contratadas para a execução de serviços contínuos - que constituem necessidade permanente - nas dependências da instituição financeira ou em instalações de terceiros por ela indicadas.

\subsubsection{Características do Setor}

A organização está inserida no setor de serviços financeiros, o qual tem por características básicas: a existência de barreiras institucionais e governamentais à entrada de novas empresas; elevada regulamentação estatal; competição básica via lançamento de novos serviços financeiros; e significativo volume de investimento e de capital como aspectos condicionantes à entrada no setor (TACHIZAWA, 2008).

Trata-se de um setor cuja rentabilidade das empresas que o compõem está, segundo Tachizawa (2008), diretamente vinculada às macropolíticas econômicas desenvolvidas pelo Estado. O autor associa, neste sentido, períodos de alta inflacionária a elevadas margens de lucro, ao passo que, alternativamente, em períodos de estabilidade econômica, a rentabilidade se baseia, de modo geral, na 
intermediação financeira e na expansão das operações normais das empresas deste mercado. Outros aspectos que influenciam marcantemente o desempenho das empresas deste setor são a captação de recursos externos e a possibilidade de crescimento por fusões e aquisições (TACHIZAWA, 2008).

\subsection{População e amostra}

Partindo da definição de Marconi e Lakatos (2005) de que a amostra se refere a uma parcela do universo de indivíduos determinada a fim de se obterem, em uma pesquisa, resultados os mais legítimos possíveis, a amostragem neste trabalho, não contemplou todos os funcionários da instituição financeira, que gira em torno de noventa e oito mil indivíduos. Restringiu-se, desta forma, a análise para a Gerência de Tributos da organização, setor que conta com uma população de setenta e quatro indivíduos. Trata-se, portanto, de uma amostragem não-probabilística, a qual não faz uso de formas aleatórias de seleção e não é, também, objeto de certos tipos de fórmulas estatísticas (Marconi; Lakatos, 2005). Foi, ainda, uma amostragem por tipicidade, o que, segundo Marconi e Lakatos (2005), implica na escolha de elementos que compõem um subgrupo organizacional com características típicas, no que concerne a um conjunto de propriedades, assumindo que os mesmos podem representar, adequadamente, uma população. A inclusão de funcionários nesta amostra obedeceu a critérios de acessibilidade, a fim de que, por meio de uma rede de contato social já estabelecida, fossem analisadas, não apenas as opiniões de empregados concursados, mas, também, de estagiários, prestadores de serviços e jovens aprendizes. Entretanto, como esta pesquisa foi realizada em uma unidade administrativa da instituição financeira, foram excluídos da amostragem os adolescentes aprendizes, tradicionalmente alocados em agências bancárias.

\subsection{Caracterização dos instrumentos de pesquisa}

Quanto à técnica, foram aplicados questionários, os quais se constituem em "uma técnica estruturada para a coleta de dados que consiste em uma série de 
perguntas escritas ou verbais, que um entrevistado responde" (MALHOTRA, 2005, p.421). Os questionários foram divididos em dois temas - Comprometimento Organizacional Afetivo e Responsabilidade Social na Dimensão Ética - e aplicados aleatoriamente, entre empregados concursados, estagiários, prestadores de serviços e jovens aprendizes que trabalham na instituição financeira.

$O$ instrumento de coleta de dados que se utilizou para aferir o compromisso de base afetiva foi a Escala de Comprometimento Organizacional Afetivo (ECOA), desenvolvida por Siqueira (1995 apud SIQUEIRA, 2008, p.55) como "[...] uma medida unidimensional que permite avaliar a intensidade com que um empregado nutre sentimentos positivos e negativos frente à organização que o emprega".

Durante a fase de construção da ECOA, dezoito sentimentos (quinze positivos e três negativos) foram selecionados para representar o vínculo afetivo do empregado com a organização. O processo de validação da escala revelou a concisão e a homogeneidade de seus dezoito itens, apresentando, como resultado, valores de correlação item-total entre 0,50 e 0,83. Além disso, a precisão da escala ( $\alpha$ de Cronbach) foi de 0,95, valor considerado altamente satisfatório (SIQUEIRA, 1995 apud SIQUEIRA, 2008). O modelo segue a Escala de Lickert, a qual consiste na elaboração de enunciados que manifestam atitudes ou opiniões relacionadas a um problema de pesquisa, segundo uma escala ordinal de valores (GIL, 1999; MARCONI; LAKATOS, 2005). No caso da ECOA, observam-se cinco pontos distintos ( 1 = nada; 2 = pouco; 3 = mais ou menos; 4 = muito; 5 = extremamente), utilizados para representar a intensidade com que os funcionários vivenciam, em uma organização, cada um dos dezoito sentimentos (SIQUEIRA, 1995 apud SIQUEIRA, 2008).

Com o objetivo de propor uma forma reduzida para a ECOA, Siqueira (1995 apud SIQUEIRA, 2008, p.55) selecionou cinco itens da escala original que detinham maior homogeneidade, para os quais foi calculado, em seguida, um novo coeficiente de precisão ( $\alpha$ de Cronbach), obtendo-se, ao final do processo, um valor igualmente satisfatório de 0,93. Assim:

"com os elevados índices de confiabilidade que detém em sua forma completa ou reduzida, a ECOA poderá ser utilizada em investigações científicas ou situações práticas de avaliação, quando for necessário mensurar o grau de comprometimento afetivo nutrido pelo empregado frente à organização [...]" (SIQUEIRA, 2008, p.56). 
No presente trabalho foi utilizada a Escala de Comprometimento Organizacional Afetivo (ECOA) em sua forma reduzida, a fim de simplificar o processo de apuração dos resultados obtidos.

Por sua vez, o instrumento de coleta de dados que se utilizou para aferir o modo como os funcionários da instituição financeira percebem as ações de Responsabilidade Social que esta empresa dirige, especificamente, para o seu público interno foi a Escala de Percepção de Comportamentos Éticos Organizacionais (EPCEO), construída e validada por Gomide Jr. et al. (2003 apud SIQUEIRA, 2008). Optou-se pela utilização da EPCEO em virtude da influência exercida pelos valores éticos no relacionamento entre a instituição financeira e seus colaboradores internos, especialmente no que concerne às principais ações socialmente responsáveis que esta organização desenvolve para seus funcionários. Outro motivo reside no fato de que a EPCEO aborda diversos aspectos pertinentes à Responsabilidade Social em sua dimensão ética, como qualidade no trabalho, respeito nas relações interpessoais, tratamento igualitário e capacitação e autodesenvolvimento (PINTO; LARA, 2004; SIQUEIRA, 2008).

A EPCEO é um instrumento de pesquisa que se desdobra em vinte itens, distribuídos, por seu turno, em dois fatores. O primeiro deles, denominado "Gestão do Sistema", é composto de quatorze itens que refletem as crenças do funcionário de que a organização possui políticas, regras e normas claras e transparentes de gestão. $O$ índice de confiabilidade ( $\alpha$ de Cronbach) obtido para este fator foi de 0,92 - considerado bastante satisfatório (GOMIDE JR. et al., 2003 apud SIQUEIRA, 2008). O segundo fator, denominado "Orientação para o Cliente", diz respeito às crenças do empregado de que a organização estabelece relações claras e honestas com seus clientes, apresentando seis itens que revelam um índice de confiabilidade ( $\alpha$ de Cronbach) equivalente a 0,82 - também considerado satisfatório pelos autores (GOMIDE JR. et al., 2003 apud SIQUEIRA, 2008).

Na EPCEO, observam-se quatro pontos distintos ( 1 = discordo totalmente; 2 = apenas discordo; 3 = apenas concordo; 4 = concordo totalmente) que sinalizam o grau de concordância dos funcionários a cada item proposto. No presente trabalho, foi feita uma livre adaptação na EPCEO, utilizando-se apenas os quatorze itens do primeiro fator (Gestão do Sistema), a fim de se restringir a análise para o âmbito interno da organização. 
Serviu como ferramenta de apoio à pesquisa o emprego de entrevistas pessoais, que são vistas por Marconi e Lakatos (2005, p.92) como um "encontro entre duas pessoas a fim de que delas se obtenham informações a respeito de determinado assunto, mediante uma conversação de natureza profissional". Neste caso, utilizou-se a entrevista pessoal semi-estruturada, cujo conceito encontra em Marconi e Lacatos (2005, p.94) a tese segundo a qual "o entrevistado tem liberdade para desenvolver cada situação na direção que o entrevistador considera adequada". Estabeleceu-se, assim, contato com um profissional que atua no setor que auxilia na coordenação do programa de Responsabilidade Social do banco.

\subsection{Procedimentos de coleta e de análise de dados}

Os dados foram coletados em Brasília (DF), no Edifício Sede da instituição financeira.

Com relação aos questionários, foi designada uma funcionária da Gerência de Tributos da empresa para fazer a distribuição dos mesmos, via Intranet e correio eletrônico - canais de comunicação amplamente utilizados pelo público interno da instituição financeira. Esta escolha foi feita devido à vasta rede social construída ao longo dos quase vinte anos que a funcionária presta serviços para o banco. $\mathrm{Na}$ medida em que se responderam aos questionários, eles foram repassados para ulterior análise. As técnicas de análise de dados envolvidas foram representadas pelo uso da ferramenta SPSS e pela aplicação de conceitos oriundos da estatística descritiva, a fim de que se migrassem os dados do questionário para os arquivos eletrônicos. Da análise de dados, chegou-se a elementos de medida central e de dispersão, sendo considerados, ademais, aspectos como freqüência, porcentagem e correlação.

Concomitantemente, procurou-se estabelecer contatos esporádicos com um funcionário que colabora com 0 desenvolvimento de ações socialmente responsáveis no banco para se debaterem questões relacionadas ao estágio em que se encontram aquelas desenvolvidas, especificamente, para o público interno da organização. Nas entrevistas, também foram objeto de debate os mecanismos por 
intermédio dos quais a empresa busca reforçar, perante seus funcionários, os valores éticos que norteiam sua política de Responsabilidade Social. 


\section{RESULTADOS E DISCUSSÃO}

\subsection{Responsabilidade social e público interno}

As informações a seguir foram extraídas de relatórios de domínio público da organização referentes ao exercício do ano de 2008 com o objetivo de se descreverem as ações de Responsabilidade Social que esta desenvolve, hoje, para o seu público interno, especificamente.

\subsubsection{Perfil dos colaboradores}

Ao fim de 2008, a instituição financeira apresentava um quadro composto por 98.491 trabalhadores diretos e indiretos. A estrutura administrativa prevê quatro categorias de profissionais. A mais numerosa delas é composta pelos colaboradores do quadro permanente, contratados pela empresa depois de serem recrutados e selecionados pela via obrigatória do concurso público. No ano passado, 78.175 pessoas formavam esse quadro. Estudantes do Ensino Médio e Ensino Superior constituíam o corpo de 11.755 estagiários, que atuavam, respectivamente, em funções administrativas e operacionais. Por sua vez, o Programa Adolescente Aprendiz, que oferece a adolescentes de 15 a 17 anos uma introdução ao mundo do trabalho, acrescentou 3.710 jovens ao time de colaboradores, no ano passado. A quarta categoria, representada pelos prestadores de serviços, totalizou um contingente de 4.851 pessoas.

A contratação desse tipo de mão de obra pelo banco obedece às determinações constantes do Termo de Ajuste de Conduta (TAC) e do Termo de Conciliação (TC), do Ministério Público do Trabalho. A política da empresa prevê a contratação de serviço terceirizado em dois casos: para execução de trabalho fora do ambiente da empresa, em espaço físico e com meios de produção fornecidos pelo contratado; e, em casos específicos, para execução de serviço, em ambiente interno, mediante justificativa técnica a ser apreciada pela área competente. A instituição financeira não contrata trabalhadores por meio de cooperativas de mão de obra para prestar serviços ligados à sua atividade-fim ou às suas atividades- 
meio, caso a execução do trabalho demande subordinação em relação ao tomador ou ao fornecedor dos serviços.

\subsubsection{Qualificação profissional}

Zelar pelo desenvolvimento pessoal e profissional da equipe de colaboradores é o fundamento da Universidade Corporativa mantida pela organização. Resultado de um trabalho focado no desenvolvimento integral das pessoas, iniciado em 1996, o órgão incentiva o trabalhador a evoluir em sua educação formal, identifica oportunidades de aprendizado e promove uma extensa e diversificada programação de atividades de formação e capacitação, tanto presenciais, em espaço físico situado na cidade de São Paulo, como a distância, por meio de ações de e-learning, ministradas pelo campus virtual na internet.

Em 2008, a Universidade Corporativa disponibilizou aos seus empregados um leque de ações educacionais que contribuem para a atuação em responsabilidade social empresarial, a excelência de atendimento, a ampliação de conhecimentos e a abertura de espaços para o debate em relação à gestão da sustentabilidade.

A empresa também aplica recursos no incentivo à educação continuada dos empregados: no ano passado, foram 1.409 benefícios para cursos de pósgraduação, 3.847 para graduação e 2.136 para aprendizado de idiomas. Seminários internos de atualização técnica e gerencial, cursos ministrados em local de trabalho, cursos seqüenciais de nível superior à distância, MBA e pós-graduação lato sensu completam o cardápio de oportunidades oferecido aos profissionais da instituição financeira.

A instituição financeira entende que quanto mais capacita, mais qualidade terá na condução dos negócios, no relacionamento com seus colaboradores e na promoção do desenvolvimento sustentável. Pensando assim, pelo terceiro ano consecutivo patrocinou a participação de gestores no Curso de Gestão Estratégica para a Sustentabilidade. O curso propicia a ampliação da visão sobre sustentabilidade nos negócios.

\subsubsection{Programa Adolescente Aprendiz}


Um dos itens de destaque, entre as iniciativas geridas pela Universidade Corporativa, é o Programa Adolescente Aprendiz, de iniciação ao mundo do trabalho por meio da capacitação em serviços bancários e administrativos. Criado para acolher jovens de famílias de baixa renda per capita (igual ou inferior a meio salário mínimo), o programa admite candidatos com idade entre 15 e 17 anos, com escolaridade mínima equivalente à $7^{\mathfrak{a}}$ série ( $8^{\circ}$ ano) do Ensino Fundamental.

Lançado em 2003, o programa contribui para a erradicação do trabalho infantil. Cada adolescente admitido recebe o acompanhamento de um colaborador voluntário, que atua como uma espécie de monitor do treinamento, organizado em módulos disponibilizados pela Universidade Corporativa. Além de ter contato com noções sobre os serviços bancários e administrativos, o jovem participante recebe orientações básicas sobre cidadania ao longo de um período de contrato que varia de 18 a 24 meses.

Ao fim da experiência, o treinamento tem a tarefa de analisar dois diferentes perfis profissionais (um, de formação técnica; outro, de nível superior), a fim de identificar as próprias aptidões e traçar um plano para seu futuro. O êxito do programa, que desde sua implantação já beneficiou mais de 10 mil adolescentes, resultou em novos frutos: no segundo semestre de 2008, a empresa implementou o Programa Jovem Aprendiz, igualmente orientado para o público de baixa renda e que abre oportunidades de emprego para jovens entre 18 e 24 anos de idade.

\subsubsection{Estagiários e ProUni}

A empresa abre, regularmente, vagas de estágio para estudantes do Ensino Médio e Ensino Superior, oriundos de estabelecimentos públicos ou privados, mediante comprovação de matrícula e freqüência. Estagiários de nível médio dão expediente em agências e postos de atendimento, ao passo que os de nível universitário (que estejam pelo menos no $5^{\circ}$ semestre de seu curso de graduação) atuam em unidades administrativas da empresa.

Em sintonia com as políticas públicas educacionais, a instituição financeira mantém convênio com o Ministério da Educação no sentido de favorecer a absorção de bolsistas do Programa Universidade para Todos (ProUni) no mercado de trabalho. Segundo o acordo, 20\% das vagas do Programa de Estágio da empresa 
são reservados a esse público - os demais $80 \%$ continuam abertos para acolher universitários não-bolsistas do ProUni.

\subsubsection{Direitos trabalhistas e relações sindicais}

Desde 2003, a empresa adota o princípio de negociação permanente com seus empregados. Havendo interesse das partes em abordar assuntos relativos à categoria, os canais de diálogo estão sempre abertos para além da data-base. Exemplos disso são os grupos de trabalho que tratam de temas específicos - como saúde ou segurança bancária - e têm caráter permanente. Sua composição respeita a paridade: $50 \%$ dos integrantes são indicados pela empresa e outros $50 \%$, pelas entidades representativas dos trabalhadores.

Instrumento indispensável para regular o relacionamento da instituição financeira com seus colaboradores, o Acordo Coletivo de Trabalho (ACT) contempla $100 \%$ dos empregados e garante plena liberdade de sindicalização, bem como a disponibilidade remunerada de colaboradores investidos de mandato sindical, preservando-Ihes todos os direitos e vantagens trabalhistas. Os trabalhadores do banco são livres para eleger seus delegados sindicais, respeitados os critérios de proporcionalidade: um delegado para cada grupo de 100 colaboradores até o limite de cinco delegados para grupos acima de 401 colaboradores.

As entidades representativas dos empregados têm à disposição, nas dependências da instituição financeira, quadros para afixação de comunicados oficiais de interesse da categoria. A cada 12 meses, a empresa compromete-se a facilitar a realização de campanha de sindicalização mediante acerto prévio com o sindicato sobre local e horário do evento.

O ACT 2008/2009 definiu conquistas importantes para os empregados do banco, entre as quais o reajuste de $10 \%$ sobre a rubrica de salário-padrão, de $10 \%$ sobre o piso salarial de mercado até $R \$ 2.500,00$ (e de $8,15 \%$ sobre o piso salarial acima de $2.500,00$ ) e de $8,15 \%$ sobre as gratificações de cargo em comissão. Para além da questão dos salários, o ACT manteve a devolução do adiantamento por ocasião do gozo das férias regulamentares em até dez parcelas iguais e sucessivas. Os colaboradores seguem com direito à isenção da anuidade dos cartões de crédito durante o período de $1^{\circ}$ de setembro de 2008 a 31 de agosto de 2009. Da mesma 
forma, empregados, aposentados e pensionistas da instituição financeira permanecem enquadrados no programa que lhes faculta redução de juros do cheque especial.

\subsubsection{Participação dos resultados}

Reconhecer o empenho individual da força de trabalho é a finalidade da política de participação nos resultados adotada pela organização. A distribuição da participação nos Lucros e Resultados (PLR) acompanha o que é negociado com a Federação Nacional dos Bancos (Fenaban). Em 2008, foi composta de uma parcela fixa de $R \$ 960,00$ e de uma parcela variável correspondente a $90 \%$ da remuneração-base, ficando a soma das parcelas limitada a um teto de $R \$ 6.301,00$ por empregado.

\subsubsection{Conselho de gestão participativa}

O modelo de gestão participativa é fundamentado na atuação dos Conselhos de Gestão Participativa (CGP), que em 2008 cumpriram seu quarto ciclo, confirmando-se como instrumento de valorização dos empregados, de melhoria dos resultados, de transparência e de busca pelo desenvolvimento sustentado. Implantada em 2004 pela Superintendência Nacional do Fundo de Garantia da organização, a iniciativa dos CGP visa incorporar e sistematizar as contribuições dos colaboradores para a tomada de decisão dos gestores. Cada CGP é formado por: um conselheiro presidente; dois a cinco conselheiros titulares, responsáveis pelas pastas: qualificação profissional e pessoal, relacionamento interno e externo, qualidade dos processos e serviços prestados, informações, qualidade de vida; conselheiros suplentes, até a mesma quantidade dos titulares.

A quantidade específica de conselheiros titulares é definida pelo CGP, juntamente com o gerente de filial ou o superintendente nacional, em assembléia.

Focados nesses cinco temas, os Conselhos de Gestão Participativa sinalizam para toda a empresa um modelo viável de inclusão dos colaboradores no processo de administração. Além de oxigenar o intercâmbio de idéias no ambiente corporativo, esse modelo tem um caráter altamente motivacional: enxergando-se 
como agente responsável pela condução dos rumos administrativos e institucionais, o empregado reforça, efetivamente, seu apreço pela empresa e seu engajamento profissional.

Entre os destaques da ação dos CGP em 2008 está a iniciativa liderada pela Gerência de Filial do FGTS de Campinas (SP), no sentido de implantar o Programa Pegada Ecológica. O objetivo da iniciativa consiste em medir o impacto da atividade daquela unidade administrativa sobre o meio ambiente, valendo-se de metodologia internacionalmente reconhecida. A partir dos volumes de energia e de matéria-prima demandados pela atividade (bem como de resíduos por ela produzidos), o modelo de cálculo estima a área de terras ecologicamente produtivas que seriam necessárias para sustentar tal consumo de recursos naturais. Para além do efeito da conscientização ambiental, o dimensionamento da "pegada ecológica" fornece aos gestores dados concretos para fundamentar as decisões sobre economia de recursos, uso racional das fontes de energia e tratamento de resíduos.

\subsubsection{Ouvidoria interna}

Trata-se de um canal de uso exclusivo do público interno para o encaminhamento de sugestões, reclamações, elogios, solicitações e denúncias aos gestores da instituição financeira. Além de fazer circular essas manifestações, cabe à Ouvidoria Interna converter as informações recebidas em subsídios que resultam em indicadores úteis para o aprimoramento de processos e a melhora progressiva do ambiente profissional.

Esse trabalho é demonstração concreta de aplicação das diretrizes definidas pela empresa de prioridade para o atendimento. Um dos desafios estratégicos da empresa é ser referencial de excelência no atendimento. Certamente, isso só pode ser alcançado com o respeito que demonstra quem responde a um registro da Ouvidoria. Cada vez mais, os gestores e empregados percebem que o canal da Ouvidoria, longe de ser um obstáculo ao banco comercial, funciona como uma consultoria rápida, direta e transparente.

\subsubsection{Diversidade}


A instituição financeira acredita nas pessoas. Por conseqüência, acredita também no respeito às diferenças como valor fundamental de uma sociedade. Essa crença tem sua expressão máxima no Programa de Diversidade do banco, que desde 2005 orienta políticas e implementa ações destinadas à promoção da diversidade, tanto dentro como fora do ambiente corporativo. A empresa foi uma das primeiras do país a estender seu Plano de Benefícios a companheiros de empregados do mesmo sexo, deliberação exemplar que mereceu destaque no Relatório Global da Organização Internacional do Trabalho (OIT).

Atitudes como a valorização das diferenças na formação de equipes e a justiça na distribuição equânime de oportunidades mantêm estreita correlação com aspectos como: melhora do clima organizacional, impulso do resultado financeiro e inovação nos modelos de gestão. A busca do diferencial competitivo, proporcionado pelo apoio à diversidade, motiva a empresa, que tem como desafio assegurar seu posto entre os melhores lugares para se trabalhar no País. Em outra vertente, o alinhamento com o Governo Federal no combate a discriminações de qualquer natureza configura-se como um dever institucional para com o próprio Brasil.

O Programa de Diversidade tem três desafios a serem superados, todos relacionados à cadeia de valor. São eles: capilarizar as ações pela rede da organização, presente em todo o País; atingir seus mais de 78 mil empregados, além de outros stakeholders importantes; sensibilizar os públicos envolvidos com a instituição financeira, disseminando a cultura, as crenças e os valores da diversidade.

Com essas preocupações em foco, a empresa planeja e executa ações de estímulo ao debate interno em todo o território nacional: seminários, chats e distribuição de cartilhas são alguns meios utilizados. Ao mesmo tempo em que a diversidade passa, cada vez mais, a figurar como pauta nos programas educacionais corporativos, a instituição financeira apóia internamente a criação de comissões e subcomissões temáticas. Em setembro de 2008, por demanda de empregados, foram instauradas as seguintes comissões nacionais: de Igualdade Racial, de Pessoas com Deficiência e de LGBT (Lésbicas, Gays, Bissexuais e Transgêneros), integrando os esforços de colaboradores de todas as regiões do País que já lidavam com os assuntos. 


\subsubsection{Ações de conscientização sobre a diversidade}

O Seminário de Diversidade da organização destaca-se no calendário corporativo como o espaço dos grandes debates sobre temas como orientação sexual, gênero, raça/etnia e deficiências. Com o apoio de três secretarias especiais da Presidência da República - de Políticas para Mulheres, de Direitos Humanos e de Políticas de Promoção da Igualdade Racial - em 2008, o evento teve como mote os "60 Anos dos Direitos Humanos". Por meio de iniciativas como essa, o Programa de Diversidade enfatiza, para a sociedade, em geral, e para seu quadro de empregados, em particular, a relevância da diversidade como um dos pilares do movimento mundial pelo respeito aos direitos humanos.

\subsubsection{Equidade}

Identificar e respeitar diferenças são os primeiros e essenciais passos rumo à adoção de políticas de equidade de gênero e de raça/etnia na ocupação de cargos de chefia e de gerência. $\mathrm{Na}$ instituição financeira, há um grande esforço nesse sentido, e uma das iniciativas que enfatiza o tratamento dado ao tema é a disponibilização de um sistema de dados que monitora, mensalmente, a distribuição de oportunidades entre homens e mulheres, brancos e negros, auferindo indicadores especialmente criados para auxiliar a gestão da equidade.

Como uma das primeiras instituições a receber, em 2006, o Selo PróEquidade de Gênero, na condição de aderente ao Programa Pró-Equidade de Gênero da Secretaria Especial de Políticas para Mulheres, a instituição financeira segue em sua missão de desenvolver novas concepções na gestão de pessoas. Em 2008, tomaram posse na empresa, para um mandato de dois anos, as subcomissões Pró-Equidade de Gênero. Sua função: disseminar a reflexão sobre a igualdade de oportunidades para homens e mulheres, dedicando atenção especial às diferenças culturais e especificidades de cada região brasileira. A idéia é sensibilizar os colaboradores da empresa, com vistas à mudança de mentalidades e atitudes. 


\subsubsection{Segurança, saúde e condições de trabalho}

O Programa Qualidade de Vida da empresa tem como objetivo estimular os empregados a incorporarem hábitos e práticas saudáveis em suas rotinas diárias dentro e fora do ambiente de trabalho. Atenta à estreita correlação entre saúde, bem-estar e produtividade, a empresa investe no combate ao sedentarismo (recorrendo ao auxílio de instituições especializadas em programas de atividades físicas), no custeio parcial do tratamento a colaboradores que querem abandonar 0 cigarro e em iniciativas de orientação e educação alimentar.

Órgão diretamente relacionado à segurança no ambiente de trabalho, a Comissão Interna de Prevenção de Acidentes (CIPA) desempenha na instituição financeira a tarefa de liderar iniciativas como o mapeamento de riscos para a saúde e a segurança no trabalho. Também compõem as atribuições da comissão monitorar a brigada voluntária de combate a incêndio, realizar eventos (como palestras sobre ergonomia e alimentação saudável) e incentivar os colaboradores a participar do programa de ginástica laboral. Em 2008, mereceram destaque, ainda, iniciativas como a instalação de novas salas de primeiros socorros e a criação de salas de repouso para os empregados.

As salas de repouso consistem num avanço importante. Atendem à necessidade de cumprir a norma legal, que prevê pausas de dez minutos a cada 50 minutos de serviços para todos os empregados que exerçam atividade de entrada de dados, sujeita a movimentos ou esforços repetitivos dos braços e da coluna vertebral. Pela regra, esse descanso tem de ser cumprido fora do posto de trabalho, mas na própria unidade em que o empregado está alocado.

O empregado do banco também tem garantido, por Acordo Coletivo de Trabalho, o direito a pagamento de adicional de insalubridade ou de periculosidade, caso seu serviço se enquadre entre as operações classificadas como insalubres ou perigosas por peritos do Ministério do Trabalho ou pela equipe de saúde da empresa.

\subsubsection{Clima organizacional}


Realizada nas unidades da empresa em 2007, a Pesquisa de Clima Organizacional teve seus resultados apresentados à alta administração em janeiro de 2008. Três meses depois, em março, a divulgação dos dados do levantamento constituiu o marco inicial do Programa de Clima Organizacional 2008, que desenvolveu medidas para melhorar o ambiente de trabalho e os relacionamentos internos, levando em conta a percepção dos empregados revelada na pesquisa, realizada a cada dois anos pela instituição financeira.

A gestão do clima organizacional é uma prática estratégica para a empresa e tem por finalidades instaurar um ambiente de trabalho que propicie o bem-estar, promover a identificação dos empregados com a instituição financeira e otimizar a produtividade das equipes em prol dos objetivos da organização - dentre os quais, o de se tornar uma das melhores empresas para se trabalhar no Brasil.

\subsection{Sobre as ações de Responsabilidade Social internas}

A análise dos dados que aludem às ações socialmente responsáveis direcionadas pela instituição financeira, especificamente, para o seu público interno permite situar a maioria destas ações no rol de, pelo menos, dois importantes indicadores de Responsabilidade Social.

O primeiro, desenvolvido por Hopkins (1997 apud ASHLEY, 2005), é um instrumento que permite avaliar o nível de compromisso de uma organização com a ética e, por conseguinte, com os anseios de seus diversos stakeholders. Neste sentido, a existência e a solidez de um código de ética permeariam fatores considerados fundamentais para o sucesso de um programa de Responsabilidade Social. No que concerne aos interesses dos colaboradores internos de uma organização, Hopkins (1997 apud ASHLEY, 2005) destaca os seguintes indicadores: subsídios e benefícios, segurança, políticas para mulheres e minorias, relacionamento entre empresa e sindicato, demissões e participação acionária dos funcionários. Entre estes indicadores, o único que não enseja ações de Responsabilidade Social na instituição financeira é aquele que prevê a existência de funcionários com direito de propriedade sobre a organização, o que é justificável, uma vez que esta é uma empresa pública e não possui capital aberto. As informações sobre o indicador demissão, por seu turno, são de mais difícil acesso, 
em comparação com os demais indicadores. Embora existam dados de domínio público sobre a quantidade de funcionários demitidos no período, não são informados a freqüência com que ocorrem estas demissões na organização, nem os critérios segundo os quais se demitem os indivíduos.

O segundo indicador foi elaborado pelo Instituto Ethos de Empresas e Responsabilidade Social, organização sem fins lucrativos cuja missão é a de mobilizar, sensibilizar e ajudar as empresas a gerir seus negócios de forma socialmente responsável, tornando-as parceiras na construção de um mundo justo e atuante em defesa da sustentabilidade. Assim, foram estabelecidos pelo instituto oito indicadores de Responsabilidade Social que são referência no Brasil, a saber: valores; transparência e governança; meio ambiente; fornecedores; consumidores e clientes; comunidade; governo e sociedade; e público interno (ETHOS, 2009).

O indicador público interno do Instituto Ethos se sustenta em três pilares: diálogo e participação, respeito ao indivíduo e trabalho decente, os quais preconizam diversas ações como relacionamento com sindicatos e trabalhadores terceirizados, gestão participativa, valorização da diversidade, compromisso com a equidade racial e de gênero, política de remuneração, benefícios e carreira, cuidados com saúde, segurança e condições de trabalho, compromisso com o desenvolvimento profissional e a empregabilidade, e preparação para aposentadoria (ETHOS, 2009).

Informações obtidas por meio de entrevista semi-estruturada com um dos funcionários responsáveis pelo desenvolvimento do programa de Responsabilidade Social da instituição financeira sinalizam uma forte influência exercida por alguns dispositivos externos no processo decisório da organização, fundamentando, assim, as ações socialmente responsáveis que a mesma direciona para o seu público interno. Neste sentido, além de ser associado ao Instituto Ethos de Empresas e Responsabilidade Social, o que reflete um compromisso com a implementação de políticas e práticas que atendam a elevados critérios éticos, o banco também é signatário do Pacto Global, iniciativa proposta pela Organização das Nações Unidas (ONU) para encorajar as empresas a adotar políticas de Responsabilidade Social e sustentabilidade.

O entrevistado destacou o apoio que a instituição financeira recebe do Instituto Ethos para a criação de células de Responsabilidade Social na organização e os esforços por ela empregados visando ao seu efetivo posicionamento em torno 
dos oito indicadores de Responsabilidade Social estabelecidos pelo instituto. Ele afirmou que, apesar de depender diretamente do incentivo do governo e, outrossim, de um panorama político estável no país, o desenvolvimento de ações socialmente responsáveis no banco se reveste, hoje, de um elevado teor de perenidade produto da consciência generalizada de que o fenômeno da Responsabilidade Social se encontra definitivamente arraigado no cotidiano da organização.

O funcionário revelou que, não obstante a carência de uma ampla base documental, as ações socialmente responsáveis dirigidas, especificamente, para o público interno da organização se encontram em um expansivo estágio de desenvolvimento, onde o estímulo ao voluntariado, o respeito à diversidade e o compromisso com a ética e a transparência desempenham um papel imprescindível. Ele, porém, ressaltou a importância da relação de sinergia existente entre estas e as demais ações de Responsabilidade Social desenvolvidas pelo banco para o atendimento dos interesses dos diversos stakeholders com os quais ele interage.

Assim, a análise das principais ações socialmente responsáveis direcionadas pela instituição financeira, especificamente, para seus colaboradores internos, parece refletir a tese segundo a qual os modelos de Responsabilidade Social incoporam idéias éticas, mesmo quando não expressos conscientemente, constituindo-se a referência normativa. Circunscrevem-se, deste modo, a padrões de comportamento ético nas organizações, motivo pelo qual estes modelos devem sempre atender a requisitos éticos mínimos estabelecidos pela sociedade onde a empresa atua (ASHLEY, 2005). Na instituição financeira, o comportamento ético é conceituado e difundido em termos do agir de modo aceito como correto pela sociedade, sem impor ou fazer aos outros aquilo que uma pessoa não aceitaria que fosse imposto por outros a ela.

\subsection{Porcentagem, medidas de tendência central, posição e dispersão de dados}

Responderam ao questionário quarenta e nove funcionários da instituição financeira, entre empregados, prestadores de serviços, estagiários e jovens aprendizes, ao longo da segunda quinzena do mês de outubro e meados de novembro do ano de 2009. Apesar da participação expressiva em termos da 
quantidade total de indivíduos que compõem o setor organizacional onde se desenvolveu a pesquisa (setenta e quatro), esta amostragem mostra-se pouco significante quando comparada com o universo populacional da organização, que gira em torno de noventa e oito mil colaboradores diretos. A seguir, apresentam-se medidas de tendência central, dispersão e posição de dados, fundamentais em pesquisas descritivas.

O gráfico 4.1 mostra a distribuição da amostra de acordo com o cargo exercido pelos funcionários respondentes.
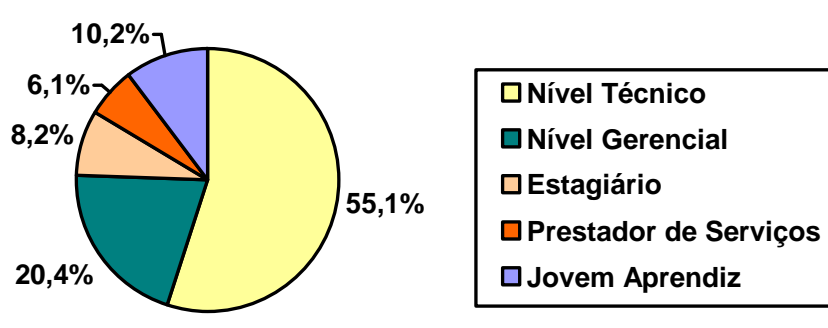

Gráfico 4.1 - Cargo ocupado na organização

Fonte: elaboração própria

A maioria dos funcionários entrevistados $(55,1 \%)$ atua no nível técnico da empresa, cujas atribuições envolvem, entre outras coisas, a prestação de serviços subserviente aos objetivos da organização (STONER; FREEMAN, 1999). Uma parcela menor $(20,4 \%)$, por outro lado, encontra-se no nível gerencial, de onde emanam as principais decisões e estratégias organizacionais (CHIAVENATO, 1983). Também fazem parte da amostra: estagiários (8,2\%), prestadores de serviços $(6,1 \%)$ e jovens aprendizes (10,2\%). Entre os quarenta e nove colaboradores internos que responderam ao questionário, vinte e dois são homens e vinte e sete são mulheres.

O gráfico 4.2 e a tabela 1 demonstram a relação existente entre cargo exercido e sexo. No que se refere a mulheres que ocupam funções gerenciais, observa-se que, ao menos no que concerne ao setor organizacional estudado, este segmento é predominante. 


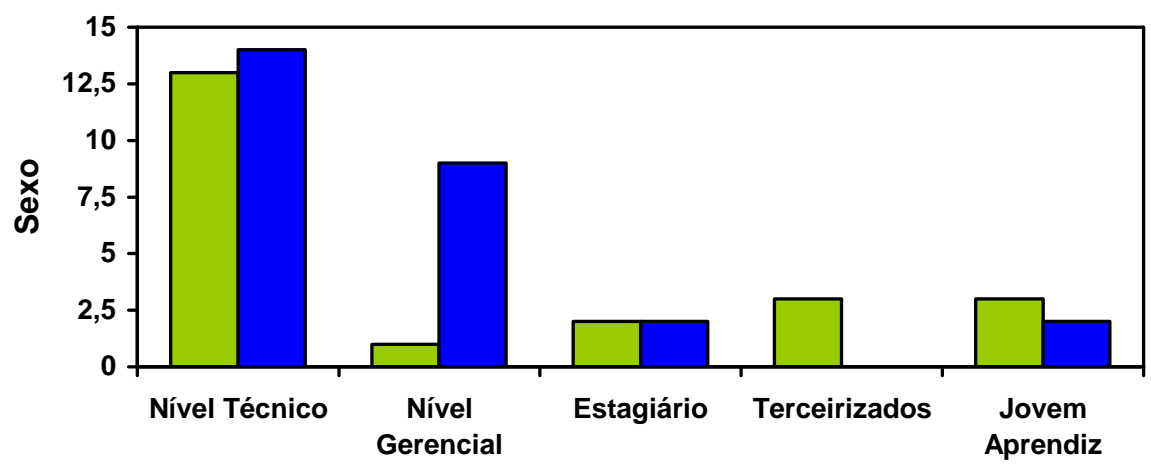

Gráfico 4.2 - Relação entre sexo e cargo ocupado na organização

Fonte: elaboração própria

A distribuição da faixa etária dos funcionários que compuseram a amostra, por sua vez, é apresentada no Gráfico 4.3 que se segue:

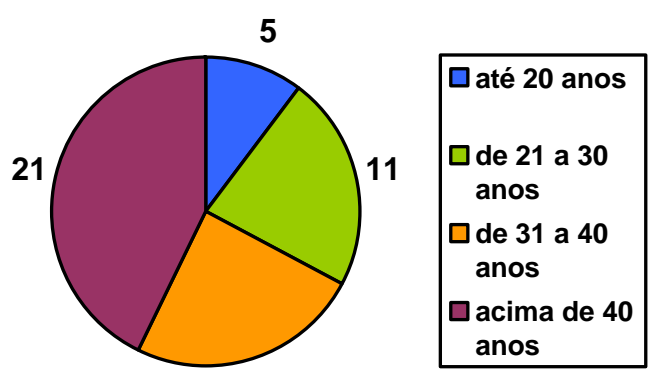

12

Gráfico 4.3 - Faixa etária dos entrevistados

Fonte: elaboração própria

Tabela 1 - Relação entre sexo e cargo ocupado na organização

\begin{tabular}{|l|c|c|}
\hline \multirow{2}{*}{ Cargo na organização } & \multicolumn{2}{c|}{ Sexo } \\
\cline { 2 - 3 } & Masculino & Feminino \\
\hline Empregados/Nível técnico & 13 & 14 \\
\hline Empregados/Nível gerencial & 1 & 9 \\
\hline Estagiários & 2 & 2 \\
\hline Terceirizados & 3 & 0 \\
\hline Jovens Aprendizes & 3 & 2 \\
\hline
\end{tabular}

Fonte: elaboração própria

O gráfico 4.4, por seu turno, relaciona a faixa etária dos funcionários ao tempo em que os mesmos trabalham na organização. Observa-se que, apesar de indivíduos com idade entre vinte e um e trinta anos constituírem a maioria dos trabalhadores com até cinco anos de tempo de serviço na empresa, esta proporção é, substantivamente, reduzida no intervalo de tempo seguinte, quando predominam 
os funcionários com idade entre trinta e um e quarenta anos. Um dos fatores explicativos possíveis para este panorama pode residir na alta rotatividade que parece acometer, nos dias de hoje, muitas organizações que integram o setor financeiro. Esta afirmativa, no entanto, só pode ser confirmada por intermédio de pesquisas e relatórios que tratam, especificamente, do assunto.

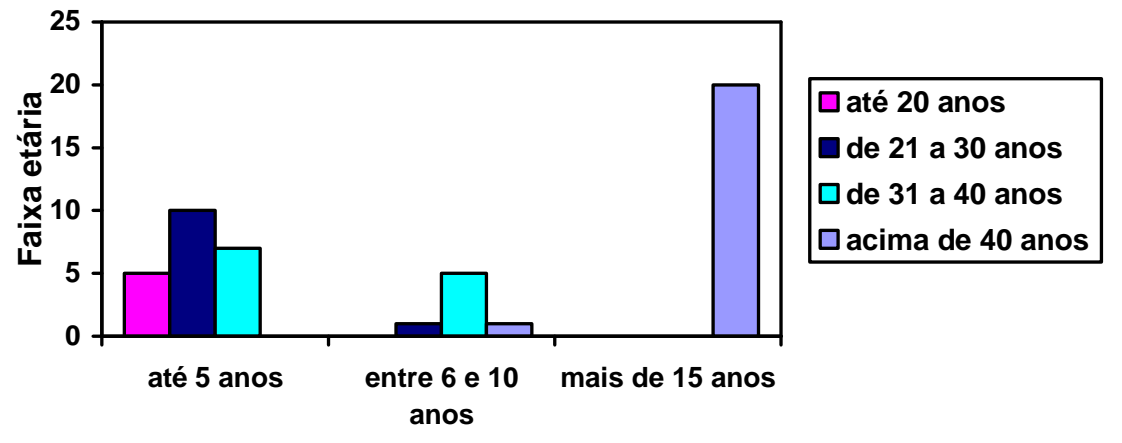

Tempo de serviço

Gráfico 4.4 - Relação entre faixa etária e tempo de serviço

Fonte: elaboração própria

Sobre o grau de instrução dos respondentes, percebeu-se que indivíduos já formados ou possuidores de outros títulos, como pós-graduação, mestrado ou doutorado, somam, aproximadamente, $77,6 \%$ da amostra total, conforme tabela 2 apresentada a seguir. Estes dados parecem sinalizar possíveis pré-requisitos adotados pelo banco para alocação de funcionários nas unidades administrativas ou, ainda, primícias da política de capacitação profissional hoje vigente na empresa.

Tabela 2 - Grau de instrução

\begin{tabular}{|l|c|c|c|}
\hline \multicolumn{1}{|c|}{ Escolaridade } & Freqüência & Porcentagem & Porcentagem acumulada \\
\hline Ensino fundamental incompleto & 1 & 2 & 2 \\
\hline Ensino médio incompleto & 4 & 8,2 & 10,2 \\
\hline Ensino médio completo & 2 & 4,1 & 14,3 \\
\hline Ensino superior incompleto & 4 & 8,2 & 22,4 \\
\hline Ensino superior completo & 4 & 8,2 & 30,6 \\
\hline $\begin{array}{l}\text { Outros (pós-graduação, mestrado, } \\
\text { doutorado, et.) }\end{array}$ & 34 & 69,4 & 100 \\
\hline
\end{tabular}

Fonte: elaboração própria

No que diz respeito às políticas de avaliação de funcionários em vigor na empresa, observa-se, entre os empregados do nível técnico, uma percepção relativamente negativa sobre as mesmas, uma vez que mais de $88 \%$ destes 
indivíduos declararam algum ceticismo quanto à existência ou eficácia destas políticas. Já entre os empregados que ocupam cargos gerenciais, o grau de concordância mostrou-se, relativamente, mais satisfatório, tendo em vista que metade dos indivíduos deste grupo reconheceram, em alguma escala, as iniciativas do banco em prol do desenvolvimento de critérios justos de avaliação de seus colaboradores internos.

Sobre as oportunidades de renovação de conhecimentos oferecidas pela instituição financeira, os entrevistados opinaram da seguinte forma: $53 \%$ dos colaboradores internos concordam, em alguma instância, que a empresa procura desenvolver mecanismos capazes de agregar conteúdo ao conhecimento, ao passo que os outros $47 \%$ da amostra declararam não atinar para estes esforços. A homogeneidade das respostas, neste caso, inviabiliza afirmativas conclusivas, mas, de modo geral, pode-se inferir que o banco, representado aqui, especialmente, no bojo das ações empreendidas por sua Universidade Corporativa, parece, aos poucos, caminhar rumo à consecução de seus objetivos.

Em se tratando das medidas de tendência central e de dispersão, a tabela 3 revela dados sobre a média, moda, mediana e desvio-padrão dos cinco itens da Escala de Comportamento Organizacional Afetivo (ECOA).

Tabela 3 - Medidas de tendência central e de dispersão para itens da ECOA

\begin{tabular}{|c|c|c|c|c|c|}
\hline \multirow{2}{*}{$\begin{array}{c}\text { Medidas de tendência } \\
\text { central e de dispersão }\end{array}$} & \multicolumn{5}{|c|}{ A empresa onde trabalho faz-me sentir com ela... } \\
\cline { 2 - 6 } & Orgulhoso & Contente & Entusiasmado & Interessado & Animado \\
\hline Média & 3,14 & 2,94 & 2,57 & 3,14 & 2,61 \\
\hline Moda & 3 & 2 & 3 & 4 & 3 \\
\hline Mediana & 3 & 3 & 3 & 3 & 3 \\
\hline Desvio-padrão & 1,021 & 1,049 & 1,041 & 1,155 & 0,975 \\
\hline
\end{tabular}

Fonte: elaboração própria

A tabela 4 mostra medidas de tendência central e de dispersão para o item que se refere à tratamento igualitário dos funcionários na Escala de Percepção de Comportamento Ético Organizacional (EPCEO). 
Tabela 4 - Medidas de tendência central e de dispersão para o item tratamento igualitário

\begin{tabular}{|c|c|c|c|}
\hline \multicolumn{4}{|c|}{ A organização trata com igualdade seus funcionários } \\
\hline $\begin{array}{c}\text { Grau de } \\
\text { concordância }\end{array}$ & Freqüência & Porcentagem & $\begin{array}{c}\text { Porcentagem } \\
\text { acumulada }\end{array}$ \\
\hline Discordo totalmente & 4 & 8,2 & 8,2 \\
\hline Apenas discordo & 9 & 18,4 & 26,5 \\
\hline Apenas concordo & 23 & 46,9 & 73,5 \\
\hline Concordo totalmente & 13 & 26,5 & 100 \\
\hline
\end{tabular}

Fonte: elaboração própria

\subsection{Aplicação, apuração dos resultados e interpretação da ECOA}

De acordo com Siqueira (1995 apud SIQUEIRA, 2008) o cômputo do escore médio de cada respondente da versão reduzida da Escala de Comportamento Organizacional Afetivo (ECOA) é obtido somando-se os valores assinalados em cada um de seus cinco itens e dividindo-se, posteriormente, este valor pelo número de itens da escala.

Siqueira (1995 apud SIQUEIRA, 2008) afirma que a interpretação dos resultados obtidos passa pelo entendimento de que, quanto maior o valor do escore médio, mais forte é o compromisso afetivo do funcionário com a organização, variando este valor entre 1 e 5 . Desta forma:

valores entre 4 e 5 podem sinalizar que o empregado sente-se afetivamente comprometido com a organização. Valores entre 3 e 3,9 sugerem indecisão do empregado quanto ao seu vínculo afetivo. Valores entre 1 e 2,9 podem indicar frágil compromisso afetivo com a organização (SIQUEIRA, 1995 apud SIQUEIRA, 2008, p.56).

O valor do escore médio que se obteve para o nível de comprometimento afetivo dos colaboradores internos da instituição financeira foi igual a 2,88163, o que, em princípio, indicaria um frágil compromisso afetivo destes funcionários com a organização.

\subsection{Aplicação, apuração dos resultados e interpretação da EPCEO}

$\mathrm{Na}$ Escala de Percepção de Comportamentos Éticos Organizacionais (EPCEO), o cálculo dos escores fatoriais médios, no fator Gestão do Sistema, utilizado neste trabalho, é obtido a partir da soma dos valores assinalados pelos 
respondentes em cada um dos itens que integra este fator, dividindo-se, em seguida, o valor encontrado por catorze - número de itens que compõem o fator. $O$ resultado obtido deverá ficar entre um e quatro (GOMIDE JR. et al., 2003 apud SIQUEIRA, 2008).

Gomide Jr. et al. (2003 apud SIQUEIRA, 2008), asseveram que, no que concerne à interpretação dos escores fatoriais médios, quanto maior o valor obtido, maior é a percepção do respondente de que sua organização apresenta comportamentos éticos quanto ao aspecto contemplado pelo fator Gestão do Sistema. Logo:

médias fatoriais iguais ou menores que 2,0 tenderiam a indicar que o empregado não percebe comportamentos éticos conforme enunciado pelo fator; médias iguais ou maiores que 3,0 tenderiam a indicar que 0 empregado percebe o comportamento ético enunciado, enquanto médias entre 2,1 e 2,9 tenderiam a indicar uma dúvida do respondente quanto á presença dos comportamentos éticos enunciados pelo fator. (GOMIDE JR. et al., 2003 apud SIQUEIRA, 2008, p. 46).

O valor do escore médio que se obteve para a percepção dos funcionários sobre o comportamento ético organizacional foi de 2,22012, índice que, em princípio, sugere dúvidas dos respondentes quanto à presença dos comportamentos éticos enunciados pelo fator Gestão do Sistema.

\subsection{Correlação entre as variáveis}

De acordo com Barbetta (2008, p. 254), "o conceito de correlação refere-se a uma associação numérica entre duas variáveis, não implicando, necessariamente, uma relação de causa e efeito, ou mesmo numa estrutura com interesses práticos". Para o autor (BARBETTA, 2008), a correlação é a forma mais indicada de se determinar a associação entre duas variáveis quantitativas que se verificam em uma população.

Sendo assim, visando aferir a relação existente entre as variáveis "Ações Internas de Responsabilidade Social" e "Comprometimento Organizacional Afetivo, correlacionaram-se as mesmas por meio do coeficiente de correlação $r_{\mathrm{s}}$ de Spearman, medida de correlação não-paramétrica que descreve, de modo sintético, 
a relação entre duas variáveis (BARBETTA, 2008).Esta tarefa se desdobrou em etapas, sendo a primeira delas a criação da tabela 5 mostrada a seguir.

Tabela 5 - Cálculo do coeficiente de correlação $r_{\mathrm{s}}$ de Spearman

\begin{tabular}{|c|c|c|c|c|c|c|}
\hline Entrevistado & $\begin{array}{c}\text { Fator } \\
\text { Comprometimento } \\
\text { Organizacional } \\
\text { Afetivo (X) }\end{array}$ & $\begin{array}{l}\text { Posto } \\
\text { de X }\end{array}$ & $\begin{array}{c}\text { Fator } \\
\text { Comportamento } \\
\text { Ético Organizacional } \\
\text { (Y) }\end{array}$ & $\begin{array}{c}\text { Posto de } \\
Y\end{array}$ & D & $D^{2}$ \\
\hline 1 & 1,00 & 1,00 & 1,43 & 3,00 & $-2,00$ & 4,00 \\
\hline 2 & 1,20 & 2,00 & 2,07 & 18,00 & $-16,00$ & 256,00 \\
\hline 3 & 1,40 & 3,00 & 2,14 & 21,50 & $-18,50$ & 342,25 \\
\hline 4 & 1,80 & 5,00 & 2,07 & 18,00 & $-13,00$ & 169,00 \\
\hline 5 & 1,80 & 5,00 & 2,36 & 30,50 & $-25,50$ & 650,25 \\
\hline 6 & 1,80 & 5,00 & 1,79 & 7,00 & $-2,00$ & 4,00 \\
\hline 7 & 2,00 & 10,00 & 1,71 & 8,50 & 1,50 & 2,25 \\
\hline 8 & 2,00 & 10,00 & 1,86 & 8,50 & 1,50 & 2,25 \\
\hline 9 & 2,00 & 10,00 & 1,43 & 3,00 & 7,00 & 49,00 \\
\hline 10 & 2,00 & 10,00 & 2,00 & 16,00 & $-6,00$ & 36,00 \\
\hline 11 & 2,00 & 10,00 & 1,79 & 11,00 & $-1,00$ & 1,00 \\
\hline 12 & 2,00 & 10,00 & 1,29 & 1,00 & 9,00 & 81,00 \\
\hline 13 & 2,00 & 10,00 & 1,50 & 3,00 & 7,00 & 49,00 \\
\hline 14 & 2,20 & 14,50 & 2,21 & 25,00 & $-10,50$ & 110,25 \\
\hline 15 & 2,20 & 14,50 & 2,21 & 25,00 & $-10,50$ & 110,25 \\
\hline 16 & 2,40 & 16,50 & 2,21 & 21,50 & $-5,00$ & 25,00 \\
\hline 17 & 2,40 & 16,50 & 2,07 & 18,00 & $-1,50$ & 2,25 \\
\hline 18 & 2,60 & 19,00 & 1,50 & 5,50 & 13,50 & 182,25 \\
\hline 19 & 2,60 & 19,00 & 2,50 & 37,00 & $-18,00$ & 324,00 \\
\hline 20 & 2,60 & 19,00 & 2,64 & 41,50 & $-22,50$ & 506,25 \\
\hline 21 & 2,80 & 21,50 & 1,71 & 11,00 & 10,50 & 110,25 \\
\hline 22 & 2,80 & 21,50 & 2,71 & 41,50 & $-20,00$ & 400,00 \\
\hline 23 & 3,00 & 23,50 & 2,14 & 21,50 & 2,00 & 4,00 \\
\hline 24 & 3,00 & 23,50 & 2,29 & 25,00 & $-1,50$ & 2,25 \\
\hline 25 & 3,20 & 26,00 & 2,43 & 37,00 & $-11,00$ & 121,00 \\
\hline 26 & 3,20 & 26,00 & 2,14 & 21,50 & 4,50 & 20,25 \\
\hline 27 & 3,20 & 26,00 & 1,86 & 11,00 & 15,00 & 225,00 \\
\hline 28 & 3,40 & 32,50 & 1,93 & 14,50 & 18,00 & 324,00 \\
\hline 29 & 3,40 & 32,50 & 2,43 & 33,50 & $-1,00$ & 1,00 \\
\hline 30 & 3,40 & 32,50 & 2,86 & 45,00 & $-12,50$ & 156,25 \\
\hline 31 & 3,40 & 32,50 & 2,00 & 13,00 & 19,50 & 380,25 \\
\hline 32 & 3,40 & 32,50 & 2,86 & 45,00 & $-12,50$ & 156,25 \\
\hline 33 & 3,40 & 32,50 & 2,36 & 30,50 & 2,00 & 4,00 \\
\hline 34 & 3,40 & 32,50 & 2,00 & 14,50 & 18,00 & 324,00 \\
\hline 35 & 3,40 & 32,50 & 2,36 & 30,50 & 2,00 & 4,00 \\
\hline 36 & 3,40 & 32,50 & 2,93 & 47,00 & $-14,50$ & 210,25 \\
\hline 37 & 3,40 & 32,50 & 2,57 & 33,50 & $-1,00$ & 1,00 \\
\hline 38 & 3,60 & 40,50 & 2,50 & 37,00 & 3,50 & 12,25 \\
\hline 39 & 3,60 & 40,50 & 2,29 & 27,50 & 13,00 & 169,00 \\
\hline 40 & 3,60 & 40,50 & 2,50 & 37,00 & 3,50 & 12,25 \\
\hline 41 & 3,60 & 40,50 & 2,50 & 37,00 & 3,50 & 12,25 \\
\hline 42 & 3,60 & 40,50 & 2,86 & 45,00 & $-4,50$ & 20,25 \\
\hline 43 & 3,60 & 40,50 & 2,71 & 43,00 & $-2,50$ & 6,25 \\
\hline 44 & 3,80 & 44,00 & 2,29 & 27,50 & 16,50 & 272,25 \\
\hline 45 & 4,00 & 46,50 & 3,14 & 48,00 & $-1,50$ & 2,25 \\
\hline 46 & 4,00 & 46,50 & 3,21 & 49,00 & $-2,50$ & 6,25 \\
\hline 47 & 4,00 & 46,50 & 1,57 & 5,50 & 41,00 & $1.681,00$ \\
\hline 48 & 4,00 & 46,50 & 2,36 & 30,50 & 16,00 & 256,00 \\
\hline 49 & 4,60 & 49,00 & 2,50 & 40,00 & 9,00 & 81,00 \\
\hline
\end{tabular}


Na tabela 5, o Fator Comprometimento Organizacional Afetivo - variável X representa o escore médio individual para cada um dos quarenta e nove entrevistados que responderam aos itens da ECOA, conforme as recomendações de Siqueira (1995 apud SIQUEIRA, 2008) citadas na seção 4.4. O Fator Comportamento Ético Organizacional - variável $Y$ - representa, por sua vez, o escore médio individual para cada um dos quarenta e nove entrevistados que responderam aos itens da EPCEO, de acordo com as instruções de Gomide Jr. et al. (2003 apud SIQUEIRA, 2008) citadas na seção 4.5.

Para cada variável são atribuídos postos da seguinte maneira: ao menor valor é atribuído o posto 1; ao segundo menor, posto 2; e assim por diante. Quando ocorre algum empate de valores, considera-se como causa uma possível deficiência do instrumento de medida, atribuindo-se, assim, postos seqüenciais por meio do cálculo da média dos postos dos valores empatados (BARBETTA, 2008).

Os valores da coluna "D" significam a diferença entre o posto de $\mathrm{X}$ e o posto de $Y$, ao passo que, em " $D^{2}$, encontra-se a diferença quadrática entre os dois postos.

O coeficiente de correlação de Spearman é obtido por meio da fórmula apresentada a seguir, situando-se seus possíveis valores no intervalo compreendido entre +1 (correlação positiva perfeita) e -1 (correlação negativa perfeita) (BARBETTA, 2008):

$$
r_{s}=1-\frac{6 \cdot \sum D^{2}}{n \cdot\left(n^{2}-1\right)}
$$

Sendo que:

a) $r_{s}$ é o coeficiente de correlação de Spearman;

b) $\sum D^{2}$ é o somatório dos valores de $D^{2}$;

c) $n$ é o tamanho da amostra;

d) $n^{2}$ é o tamanho da amostra ao quadrado.

Fazendo-se os cálculos, tem-se que:

$$
r s=1-\frac{6 \cdot \sum D^{2}}{n \cdot\left(n^{2}-1\right)}=1-\frac{6 \cdot(7 \cdot 881,00)}{49 \cdot\left(49^{2}-1\right)}=1-0,4020918=0,5979080
$$


O nível de significância, segundo Barbetta (2008), indica a probabilidade de se incorrer em erro ao se rejeitar $\mathrm{H}_{0}$, quando $\mathrm{H}_{0}$ é verdadeira. Em pesquisa social, o nível de significância geralmente utilizado é de 0,05. Na presente pesquisa, adotando-se um nível de significância de $5 \%$, há um risco muito pequeno de se errar ao optar pela veracidade de $\mathrm{H}_{1}$ em detrimento de $\mathrm{H}_{0}$, no caso de $\mathrm{H}_{0}$ ser verdadeira.

Uma vez estimado o coeficiente de correlação de Spearman, encontraram-se os valores mínimos de $r_{s}$ para que haja correlação significativa, em função do nível de significância (Tabela 6).

Tabela 6 - Valor mínimo para o coeficiente de correlação $r_{s}$ de Spearman ser significativo

\begin{tabular}{|c|c|c|c|c|c|c|}
\hline & \multicolumn{7}{|c|}{ Nível de significância $\alpha$} \\
\hline $\mathbf{N}$ & 0,200 & 0,100 & 0,050 & 0,020 & 0,020 & 0,010 \\
\hline 45 & 0,193 & 0,248 & 0,295 & 0,351 & 0,388 & 0,466 \\
\hline 50 & 0,183 & 0,235 & 0,280 & 0,332 & 0,368 & 0,441 \\
\hline 60 & 0,167 & 0,214 & 0,255 & 0,303 & 0,335 & 0,402 \\
\hline
\end{tabular}

Fonte: Barbetta, 2008 (adaptado)

Observa-se que, ao se adotar um nível de significância de 5\%, o valor mínimo para o coeficiente de correlação $r_{s}$ de Spearman, em uma amostra de quarenta e cinco a cinqüenta elementos, situa-se entre 0,295 e 0,280. A correlação linear positiva, cujo $r_{s}$ equivale a 0,5979082 , parece refletir, no caso das duas variáveis de que trata a pesquisa, um grau de correlação relativamente satisfatório. 


\section{CONCLUSÕES E RECOMENDAÇÕES}

A presente pesquisa esboçou-se no atual contexto de profundas mudanças econômicas, sociais e políticas pelas quais o mundo vem passando nas últimas décadas, que engendram, por sua vez, uma tendência de redefinição nos modelos de negócio das organizações modernas. Assim, a Responsabilidade Social, entendida aqui como o relacionamento ético e responsável da empresa perante seus diversos stakeholders, hoje, começa a ganhar destaque no arcabouço de várias práticas gerenciais vanguardistas, uma vez que se afirma que ela pode fornecer à organização diversas vantagens competitivas, entre as quais a de servir como mecanismo indutor de comprometimento organizacional.

Deste modo, objetivou-se relacionar o comprometimento afetivo dos funcionários da instituição financeira ao modo como eles percebem as ações de Responsabilidade Social que esta organização direciona, especificamente, para o seu público interno, à luz do comportamento ético organizacional. Apresentam-se, a seguir, algumas conclusões e lacunas desta pesquisa, bem como idéias para novos estudos e análises sobre o tema em questão.

A correlação que a pesquisa sugere entre comprometimento organizacional afetivo e percepção dos funcionários acerca das ações internas de Responsabilidade Social desenvolvidas pela instituição financeira possui caráter inconclusivo, podendo ser justificada em termos de algumas limitações deste trabalho.

Em primeiro lugar, deve-se ressaltar que o tamanho da amostragem contemplada nesta pesquisa não representa, adequadamente, 0 universo populacional da organização, que gira em torno de noventa e oito mil colaboradores internos. Este fato acarreta conseqüências sobre o poder do teste de inferência estatística, que traduz a probabilidade de se rejeitar corretamente a hipótese nula (H0) quando a mesma é falsa, interferindo, ainda, no tamanho do efeito - estimativa do grau em que o fenômeno de correlação entre variáveis existe na organização (HAIR et al., 1998).

Outro fator passível de ressalvas alude ao período em que se realizou esta pesquisa - concomitante ao movimento grevista que mobilizou bancários de todo 0 
país entre os meses de setembro e outubro do ano de 2009. Neste sentido, deve-se ponderar os vieses interpretativistas oriundos do clima tenso e acirrado que costuma acompanhar as negociações coletivas da categoria, os quais podem ter influenciado, de alguma maneira, as respostas de alguns participantes da pesquisa.

Além disso, utilizou-se, nesta pesquisa, uma abordagem unidimensional de comprometimento, escolha que, apesar de relevante para a consecução dos objetivos do trabalho, acaba por ofuscar uma análise global e integrada do assunto, igualmente necessária na atual realidade das organizações modernas.

Deve-se chamar atenção, outrossim, para a escassez de instrumentos de pesquisa capazes de mensurar, pontualmente, a percepção dos funcionários de uma empresa quanto às ações de Responsabilidade Social que esta desenvolve, especificamente, para eles. Assim, na esteira do desenvolvimento da temática da Responsabilidade Social, os pesquisadores, hoje, parecem se preocupar, via de regra, com estudos mais abrangentes, focalizando todas as quatro dimensões que norteiam este conceito - econômica, legal, ética e filantrópica - bem como os interesses dos vários grupos de stakeholders que interagem com a organização tomados coletivamente.

Por fim, o significado da presente pesquisa reside no estímulo que ela pode oferecer a futuros estudos que se proponham a analisar, isoladamente, indicadores de Responsabilidade Social, a fim de conferir praticidade e rapidez ao atendimento de diversas demandas das organizações por envolverem, neste sentido, um menor número de variáveis e atores ao longo do processo. 


\section{REFERÊNCIAS}

ANDREASEN, Alan R. (Org.). Ética e marketing social: como conciliar os interesses do cliente, da empresa e da sociedade numa ação de marketing. Tradução Bazán Tecnologia e Lingüística. São Paulo: Futura, 2002.

ASHLEY, Patrícia Almeida (Coord.). Ética e responsabilidade social nos negócios. Apresentação Maria Cecilia Arruda. 2. ed. São Paulo: Saraiva, 2005.

BARBETTA, Pedro Alberto. Estatística aplicada às ciências sociais. 7.ed. Florianópolis: Ed. da UFSC, 2008.

BRIGHAM, E. F.; HOUSTON, J. F. Fundamentos da moderna administração financeira. Tradução Maria Imilda da Costa e Silva. Rio de Janeiro: Elsevier, 1999.

CHIAVENATO, Idalberto. Introdução à teoria geral da administração. 3. ed. São Paulo: McGraw-Hill do Brasil, 1983.

COUTINHO, R. B. G.; MACEDO-SOARES, T. D. L. V. A. Gestão estratégica com responsabilidade social: um arcabouço analítico para auxiliar sua implementação em empresas no Brasil. Revista de Administração Contemporânea, [S.I.], v. 6, n. 3, p. 75-96, set./dez. 2002. ISSN 1415-6555.

DESSLER, Gary. Administração de recursos humanos. Tradução Cecília Leão Oderich. 2. ed. São Paulo: Prentice Hall, 2003.

ENRIQUEZ, Eugène. Os desafios éticos nas organizações modernas. Revista de Administração de Empresas, São Paulo, v. 37, n. 2, p. 6-17, abr./jun. 1997. ISSN 0034-7590.

ETHOS. Indicadores Ethos de responsabilidade social empresarial. Disponível em: <www.ethos.org.br/docs/conceitos_praticas/indicadores/default.asp $>$. Acesso em: 06 nov. 2009.

GIL, Antônio Carlos. Métodos e técnicas de pesquisa social. 5. ed. São Paulo: Atlas, 1999.

GONÇALVES, Carlos Alberto; MEIRELLES, Anthero de Moraes. Projetos e relatórios de pesquisa em administração. São Paulo: Atlas, 2004. 
HAIR, Joseph F. et al. Análise multivariada de dados. 5. ed. Porto Alegre: Artmed; [S.I.]: Bookman, 1998.

HOBSBAWN, Eric. Era dos extremos: o breve século XX... Tradução: Marcos Santarrita. 2. ed. São Paulo: Companhia das Letras, 2003.

KOTLER, Philip; ROBERTO, Eduardo L. Marketing social: estratégias para alterar o comportamento público. São Paulo: Campus, 1992.

MACHADO FILHO, Cláudio Pinheiro. Responsabilidade social e governança: o debate e as implicações. São Paulo: Pioneira Thomson Learning, 2006.

MALHOTRA, Naresk K. Introdução à pesquisa de marketing. 1. ed. São Paulo: Prentice Hall, 2005.

MARCONI, Maria de Andrade; LAKATOS, Eva Maria. Técnicas de pesquisa. 5. ed. São Paulo: Atlas, 2002.

MCINTOSH, Malcolm et al. Cidadania corporativa: estratégias bem-sucedidas para empresas responsáveis. Tradução Bazán Tecnologia e Lingüística. Rio de Janeiro: Qualitymark, 2001.

MEDEIROS, C. A. F. et al. Comprometimento organizacional: o estado da arte da pesquisa no Brasil. Revista de Administração Contemporânea, [S.I.], v.7, n. 4, p. 187-209, out./dez. 2003. ISSN 1415-6555.

MOREIRA, Joaquim Manhães. A ética empresarial no Brasil. São Paulo: Pioneira Thomson Learning, 2002.

MORGAN, Gareth. Imagens da organização. Tradução Cecília Whitaker Bergamini, Roberto Coda. São Paulo: Atlas, 1996.

PINTO, Marcelo de Rezende; LARA, José Edson. A cidadania corporativa como uma orientação de marketing: um estudo no varejo. Revista de Administração de Empresas, Minas Gerais, v. 44, ed. especial, p. 48-60, nov./dez. 2004. ISSN 00347590. 
RIBEIRO, Carlos A. C. A responsabilidade social da empresa: uma nova vantagem competitiva. Revista de Administração de Empresas, São Paulo, v. 33, n. 1, p. 4650, jan./fev. 1993. ISSN 0034-7590.

RICHARDSON, Roberto Jarry. Pesquisa social: métodos e técnicas. 3. ed. São Paulo: Atlas, 1999.

SIQUEIRA, Mirlene Maria Matias (Org.). Medidas do comportamento organizacional: ferramentas de diagnóstico e de gestão. Porto Alegre: Artmed; [S.I.]: Bookman, 2008.

STONER, James A.F.; FREEMAN, R. Edward. Administração. 5.ed. Rio de Janeiro: LTC, 1999.

TACHIZAWA, Takeshy. Gestão ambiental e responsabilidade social corporativa: estratégias de negócios focadas na realidade brasileira. 5. ed. rev. e amp. São Paulo: Atlas, 2008.

TENÓRIO, Fernando Guilherme (Org.). Responsabilidade social empresarial: teoria e prática. Rio de Janeiro: FGV, 2004.

TOLEDO, Geraldo Luciano. Marketing bancário: análise, planejamento, processo decisório. São Paulo: Atlas, 1978.

WEBER, Max. A ética protestante e o espírito do capitalismo. Tradução de $M$. Irene de Q. F. Szmrecsányi; Tamás J. M. K. Szmrecsányi. 5. ed. São Paulo: Pioneira: 1987.

ZYLBERSZTAJN, Decio. Organização ética: um ensaio sobre comportamento e estrutura das organizações. Revista de Administração Contemporânea, [S.I.], v. 6, n. 2, p. 123-143, maio/ago. 2002. ISSN 1415-6555. 


\section{APÊNDICE}

\section{Apêndice A: Questionário}

\section{PESQUISA - APRESENTAÇÃO}

Este questionário é um instrumento de coleta de dados voltado à realização do trabalho de conclusão de curso do aluno GEOVANI TEIXEIRA BARROSO, matrícula 04/31702, do curso de Administração de Empresas da Universidade de Brasília - UnB.

O trabalho busca fazer uma análise da relação entre Responsabilidade Social, enquanto conjunto de práticas orientadas pelo comportamento ético nas organizações, e comprometimento organizacional afetivo. A pesquisa está sendo desenvolvida sob a orientação da Prof ${ }^{a}$. Dra. Mylene Pítsica Marques.

\section{IMPORTANTE}

- A pesquisa terá tratamento estatístico e suas respostas ficarão totalmente anônimas. Haverá sigilo total quanto ao nome do entrevistado e a outros dados que possam identificá-lo na apresentação da pesquisa.

- O questionário se divide em três seções: dados pessoais e profissionais; comprometimento organizacional afetivo; e comportamento ético da organização.

- Leia atentamente as instruções no início de cada seção antes de assinalar sua resposta.

- Verifique se todas as questões foram preenchidas.

\section{Agradecemos a sua colaboração!!!}




\section{SEÇÃO I - DADOS PESSOAIS E PROFISSIONAIS}

Nesta etapa do questionário, pedimos que você assinale, para cada uma das cinco questões a seguir, a alternativa que melhor se adapta ao seu perfil.

\section{1 - Marque sua faixa etária:}
( ) Até 20 anos
( ) De 31 a 40 anos
( ) De 21 a 30 anos
( ) Acima de 40 anos

2 - Sexo:
( ) Masculino
( ) Feminino

\section{3 - Qual é o seu grau de instrução?}
( ) Ensino Fundamental incompleto ( ) Ensino Superior incompleto
( ) Ensino Fundamental completo ( ) Ensino Superior completo
( ) Ensino Médio incompleto （ ) Outros (pós-graduação, mestrado, doutorado, etc.)
( ) Ensino Médio completo

4 - Há quanto tempo você trabalha na organização?
( ) Até 5 anos
( ) Entre 10 e 15 anos
( ) Entre 6 e 10 anos
( ) Mais de 15 anos

\section{5 - Qual é o seu cargo nesta organização?}
( ) Empregado / Nível Técnico
( ) Prestador de Serviços Externos
( ) Empregado / Nível Gerencial
( ) Jovem Aprendiz
( ) Estagiário 


\section{SEÇAO II - COMPROMETIMENTO ORGANIZACIONAL AFETIVO}

Abaixo estão listados cinco sentimentos que alguém poderia ter em relação à empresa onde trabalha. Gostaríamos de saber o quanto você sente estes sentimentos. Dê suas respostas anotando, nos parênteses que antecedem cada frase, aquele número (de 1 a 5) que melhor representa sua resposta.

$$
\begin{aligned}
& 1=\text { Nada } \\
& 2=\text { Pouco } \\
& 3=\text { Mais ou menos } \\
& 4=\text { Muito } \\
& 5=\text { Extremamente }
\end{aligned}
$$

\section{A empresa onde trabalho faz-me sentir...}

( ) Orgulhoso dela.

( ) Contente com ela.

( ) Entusiasmado com ela.

( ) Interessado por ela.

( ) Animado com ela. 


\section{SEÇÃO III - COMPORTAMENTO ÉTICO DA ORGANIZAÇÃO}

A seguir, estão frases que podem traduzir o que você pensa sobre seu trabalho e sobre a organização onde você trabalha. Assinale sua opinião sobre cada uma delas, anotando, nos parênteses, sua concordância conforme os códigos abaixo:

$$
\begin{array}{ll}
1=\text { Discordo totalmente } & 3=\text { Apenas concordo } \\
2=\text { Apenas discordo } & 4=\text { Concordo totalmente }
\end{array}
$$

\section{A empresa onde eu trabalho...}

( ) ... oferece oportunidade para a correção de erros.

( ) ... trata com igualdade a todos os empregados.

( ) ... trata seus empregados, na empresa, como possuidores de direitos e deveres.

( ) ... reconhece, publicamente, dentro e/ou fora da empresa, os trabalhos bem feitos.

( ) ... possui políticas que impedem que seus empregados sejam humilhados e/ou discriminados na empresa.

( ) ... estabelece prazos compatíveis com as tarefas a serem executadas.

( ) ... possui objetivos que são conhecidos por todos.

( ) ... possui políticas justas de avaliação de seus empregados.

( ) ... possui políticas que permitem a participação de todos os envolvidos nas tomadas de decisão.

( ) ... possui políticas que permitem aos gerentes permanente renovação de seus conhecimentos.

( ) ... possui políticas que são conhecidas por todos.

( ) ... possui regras e normas que foram definidas a partir da consulta a todos os envolvidos.

( ) ... possui políticas que permitem aos empregados contínua revisão de seus conhecimentos.

( ) ... não modifica as regras e normas sem prévia consulta aos envolvidos. 


\section{Apêndice B: Roteiro de Entrevista Semi-Estruturada}

1) Apresentação do aluno e de sua instituição de ensino, seguida de comentários introdutórios sobre a pesquisa e de uma palavra de agradecimento ao entrevistado pela sua participação;

2) Modo como a organização concebe a temática da Responsabilidade Social;

3) Ações socialmente responsáveis voltadas para o público interno;

4) Sugestões de pesquisas sobre Responsabilidade Social que podem contribuir com o desenvolvimento da organização. 


\section{ANEXOS}

\section{ANEXO A: Escala de comprometimento organizacional afetivo - ECOA}

Abaixo estão listados vários sentimentos que alguém poderia ter em relação à empresa onde trabalha. Gostaríamos de saber o quanto você sente estes sentimentos. Dê suas respostas anotando, nos parênteses que antecedem cada frase, aquele número (de 1 a 5 ) que melhor representa sua resposta.

$$
\begin{aligned}
& 1=\text { Nada } \\
& 2=\text { Pouco } \\
& 3=\text { Mais ou menos } \\
& 4=\text { Muito } \\
& 5=\text { Extremamente }
\end{aligned}
$$

A empresa onde trabalho faz-me sentir...

( ) Confiante nela.

( ) Desgostoso com ela. **

( ) Empolgado com ela.

( ) Fiel a ela.

( ) Apegado a ela.

( ) Orgulhoso dela. ${ }^{\circledR}$

( ) Contente com ela. ${ }^{\circledR}$

( ) Responsável por ela. 
( ) Distante dela. **

( ) Dedicado a ela.

( ) Entusiasmado com ela. ${ }^{\circledR}$

( ) Preocupado com ela.

( ) Encantado com ela.

( ) Desiludido com ela. **

( ) Envolvido com ela.

( ) Fascinado por ela.

( ) Interessado por ela. $\mathbb{B}$

( ) Animado com ela. ${ }^{\circledR}$

${ }^{\circledR}$ Itens da forma reduzida, utilizados neste trabalho.

** Itens com formulação negativa. 


\section{Anexo B: Escala de percepção de comportamentos éticos organizacionais - EPCEO}

A seguir, estão frases que podem traduzir o que você pensa sobre seu trabalho e sobre a organização onde você trabalha. Assinale sua opinião sobre cada uma delas, anotando, nos parênteses, sua concordância conforme os códigos abaixo:

1 = Discordo totalmente

2 = Apenas discordo

$3=$ Apenas concordo

4 = Concordo totalmente

\section{A empresa onde eu trabalho...}

( ) ... oferece oportunidade para a correção de erros.

( ) ... oferece seus produtos a preços competitivos. **

( ) ... oferece seus produtos nos prazos prometidos. **

( ) ... presta informações precisas e objetivas a seus clientes, quando solicitada. ${ }^{*}$

( ) ... respeita e valoriza seus clientes. ${ }^{* *}$

( ) ... trata com igualdade a todos os empregados.

( ) ... trata seus empregados, na empresa, como possuidores de direitos e deveres.

( ) ... busca assegurar honestidade em suas transações com seus clientes. ${ }^{* *}$

( ) ... reconhece, publicamente, dentro e/ou fora da empresa, os trabalhos bem feitos.

( ) ... possui políticas que impedem que seus empregados sejam humilhados e/ou discriminados na empresa. 
( ) ... estabelece prazos compatíveis com as tarefas a serem executadas.

( ) ... possui objetivos que são conhecidos por todos.

( ) ... possui políticas justas de avaliação de seus empregados.

( ) ... possui políticas que permitem a participação de todos os envolvidos nas tomadas de decisão.

( ) ... possui políticas que permitem aos gerentes permanente renovação de seus conhecimentos.

( ) ... possui políticas que são conhecidas por todos.

( ) ... possui regras e normas que foram definidas a partir da consulta a todos os envolvidos.

( ) ... responde, de maneira precisa, às demandas de sua clientela. **

( ) ... possui políticas que permitem aos empregados contínua revisão de seus conhecimentos.

( ) ... não modifica as regras e normas sem prévia consulta aos envolvidos.

** Itens do fator "Orientação para o Cliente", excluídos da versão final do questionário. 
Anexo C: Valores para o coeficiente de correlação de Spearman

\begin{tabular}{|c|c|c|c|c|c|c|c|c|c|c|}
\hline $\begin{array}{c}\alpha(2) \\
\alpha(1) \\
n\end{array}$ & & $\begin{array}{l}0.5 .0 \\
0.25\end{array}$ & $\begin{array}{l}0.20 \\
0.10\end{array}$ & $\begin{array}{l}0.10 \\
0.0 .5\end{array}$ & $\begin{array}{l}0.0 .5 \\
0.0 .25\end{array}$ & $\begin{array}{l}0.0 .2 \\
0.0 .1\end{array}$ & $\begin{array}{l}0.01 \\
0.005\end{array}$ & $\begin{array}{l}0.0 .05 \\
0.0025\end{array}$ & $\begin{array}{l}0.002 \\
0.001\end{array}$ & $\begin{array}{l}0.001 \\
0.0005\end{array}$ \\
\hline $\begin{array}{l}4 \\
5\end{array}$ & i & $\begin{array}{l}0.600 \\
0.500\end{array}$ & $\begin{array}{l}1.0 .00 \\
0.8 .00\end{array}$ & $\begin{array}{l}1 \cdot 0.00 \\
0.9 .00\end{array}$ & 1.000 & 1.000 & & & & \\
\hline $\begin{array}{r}6 \\
7 \\
8 \\
9 \\
10\end{array}$ & $\begin{array}{l}1 \\
1 \\
1 \\
1\end{array}$ & $\begin{array}{l}0.371 \\
0.321 \\
0.310 \\
0.267 \\
0.248\end{array}$ & $\begin{array}{l}0.657 \\
0.5 .71 \\
0.5 .24 \\
0.4 .83 \\
0.4 .55\end{array}$ & $\begin{array}{l}0.8 .29 \\
0.714 \\
0.643 \\
0.600 \\
0.5 .64\end{array}$ & $\begin{array}{l}0.886 \\
0.786 \\
0.738 \\
0.7 .00 \\
0.648\end{array}$ & $\begin{array}{l}0.943 \\
0.893 \\
0.833 \\
0.7 .83 \\
0.745\end{array}$ & $\begin{array}{l}1.000 \\
0.929 \\
0.881 \\
0.833 \\
0.794\end{array}$ & $\begin{array}{l}1.000 \\
0.964 \\
0.905 \\
0.867 \\
0.830\end{array}$ & $\begin{array}{l}1.000 \\
0.952 \\
0.917 \\
0.879\end{array}$ & $\begin{array}{l}1.000 \\
0.976 \\
0.933 \\
0.903\end{array}$ \\
\hline $\begin{array}{l}11 \\
12 \\
13 \\
14 \\
15\end{array}$ & $\begin{array}{l}1 \\
1 \\
1 \\
1\end{array}$ & $\begin{array}{l}0.236 \\
0.217 \\
0.209 \\
0.200 \\
0.189\end{array}$ & $\begin{array}{l}0.4 .27 \\
0.4 .06 \\
0.385 \\
0.367 \\
0.354\end{array}$ & $\begin{array}{l}0.5 .36 \\
0.5 .03 \\
0.4 .84 \\
0.464 \\
0.4 .46\end{array}$ & $\begin{array}{l}0.618 \\
0.5 .87 \\
0.560 \\
0.538 \\
0.521\end{array}$ & $\begin{array}{l}0.709 \\
0.678 \\
0.6 .48 \\
0.626 \\
0.6 .04\end{array}$ & $\begin{array}{l}0.755 \\
0.727 \\
0.703 \\
0.679 \\
0.654\end{array}$ & $\begin{array}{l}0.800 \\
0.769 \\
0.747 \\
0.723 \\
0.7 .00\end{array}$ & $\begin{array}{l}0.845 \\
0.818 \\
0.791 \\
0.771 \\
0.750\end{array}$ & $\begin{array}{l}0.873 \\
0.846 \\
0.824 \\
0.802 \\
0.779\end{array}$ \\
\hline $\begin{array}{l}16 \\
17 \\
18 \\
19 \\
20\end{array}$ & $\begin{array}{l}i \\
i \\
i \\
i\end{array}$ & $\begin{array}{l}0.182 \\
0.176 \\
0.170 \\
0.165 \\
0.161\end{array}$ & $\begin{array}{l}0.3 .41 \\
0.328 \\
0.317 \\
0.3 .09 \\
0.299\end{array}$ & $\begin{array}{l}0.429 \\
0.4 .14 \\
0.4 .01 \\
0.3 .91 \\
0.380\end{array}$ & $\begin{array}{l}0.503 \\
0.485 \\
0.472 \\
0.460 \\
0.447\end{array}$ & $\begin{array}{l}0.582 \\
0.566 \\
0.550 \\
0.535 \\
0.520\end{array}$ & $\begin{array}{l}0.635 \\
0.615 \\
0.6 .00 \\
0.584 \\
0.570\end{array}$ & $\begin{array}{l}0.679 \\
0.662 \\
0.643 \\
0.628 \\
0.612\end{array}$ & $\begin{array}{l}0.729 \\
0.713 \\
0.695 \\
0.677 \\
0.662\end{array}$ & $\begin{array}{l}0.762 \\
0.748 \\
0.728 \\
0.712 \\
0.696\end{array}$ \\
\hline $\begin{array}{l}21 \\
22 \\
23 \\
24 \\
25\end{array}$ & $\begin{array}{l}1 \\
1 \\
1 \\
1\end{array}$ & $\begin{array}{l}0.156 \\
0.152 \\
0.148 \\
0.144 \\
0.142\end{array}$ & $\begin{array}{l}0.292 \\
0.2,84 \\
0.278 \\
0.271 \\
0.2 .65\end{array}$ & $\begin{array}{l}0.3 .70 \\
0.3 .61 \\
0.3 .53 \\
0.344 \\
0.3 .37\end{array}$ & $\begin{array}{l}0.435 \\
0.425 \\
0.4 .15 \\
0.406 \\
0.398\end{array}$ & $\begin{array}{l}0.5 .08 \\
0.4 .96 \\
0.486 \\
0.476 \\
0.466\end{array}$ & $\begin{array}{l}0.556 \\
0.544 \\
0.532 \\
0.521 \\
0.511\end{array}$ & $\begin{array}{l}0.599 \\
0.586 \\
0.573 \\
0.562 \\
0.5 .51\end{array}$ & $\begin{array}{l}0.648 \\
0.634 \\
0.622 \\
0.610 \\
0.598\end{array}$ & $\begin{array}{l}0.681 \\
0.667 \\
0.654 \\
0.642 \\
0.630\end{array}$ \\
\hline $\begin{array}{l}26 \\
27 \\
28 \\
29 \\
30\end{array}$ & $\begin{array}{l}i \\
i \\
i \\
i\end{array}$ & $\begin{array}{l}0.138 \\
0.136 \\
0.133 \\
0.130 \\
0.128\end{array}$ & $\begin{array}{l}0.259 \\
0.255 \\
0.250 \\
0.245 \\
0.240\end{array}$ & $\begin{array}{l}0.331 \\
0.324 \\
0.317 \\
0.312 \\
0.306\end{array}$ & $\begin{array}{l}0.3 .90 \\
0.3 .82 \\
0.3 .75 \\
0.3 .68 \\
0.3 .62\end{array}$ & $\begin{array}{l}0.457 \\
0.448 \\
0.440 \\
0.4 .33 \\
0.425\end{array}$ & $\begin{array}{l}0.501 \\
0.491 \\
0.483 \\
0.477 \\
0.467\end{array}$ & $\begin{array}{l}0.541 \\
0.531 \\
0.522 \\
0.513 \\
0.504\end{array}$ & $\begin{array}{l}0.587 \\
0.577 \\
0.567 \\
0.558 \\
0.549\end{array}$ & $\begin{array}{l}0.619 \\
0.608 \\
0.598 \\
0.589 \\
0.580\end{array}$ \\
\hline $\begin{array}{l}31 \\
32 \\
33 \\
34 \\
35\end{array}$ & $\begin{array}{l}i \\
i \\
i \\
i\end{array}$ & $\begin{array}{l}0.126 \\
0.124 \\
0.121 \\
0.120 \\
0.118\end{array}$ & $\begin{array}{l}0.236 \\
0.232 \\
0.229 \\
0.225 \\
0.222\end{array}$ & $\begin{array}{l}0.3 .01 \\
0.2 .96 \\
0.2 .91 \\
0.287 \\
0.283\end{array}$ & $\begin{array}{l}0.356 \\
0.3 .50 \\
0.345 \\
0.340 \\
0.335\end{array}$ & $\begin{array}{l}0.418 \\
0.412 \\
0.4 .05 \\
0.399 \\
0.3 .94\end{array}$ & $\begin{array}{l}0.4 .59 \\
0.452 \\
0.446 \\
0.439 \\
0.4 .33\end{array}$ & $\begin{array}{l}0.4 .96 \\
0.489 \\
0.4 .82 \\
0.475 \\
0.4 .68\end{array}$ & $\begin{array}{l}0.541 \\
0.533 \\
0.525 \\
0.517 \\
0.510\end{array}$ & $\begin{array}{l}0.571 \\
0.563 \\
0.554 \\
0.547 \\
0.539\end{array}$ \\
\hline $\begin{array}{l}36 \\
37 \\
38 \\
39 \\
40\end{array}$ & $\begin{array}{l}i \\
i \\
i \\
i \\
i\end{array}$ & $\begin{array}{l}0.116 \\
0.114 \\
0.113 \\
0.111 \\
0.110\end{array}$ & $\begin{array}{l}0.219 \\
0.216 \\
0.2112 \\
0.210 \\
0.2 .07\end{array}$ & $\begin{array}{l}0.279 \\
0.275 \\
0.271 \\
0.2 .67 \\
0.2 .64\end{array}$ & $\begin{array}{l}0.330 \\
0.3 .25 \\
0.321 \\
0.3117 \\
0.3 .13\end{array}$ & $\begin{array}{l}0.3 .88 \\
0.3 .83 \\
0.3 .78 \\
0.3 .73 \\
0.3 .68\end{array}$ & $\begin{array}{l}0.427 \\
0.4 .21 \\
0.415 \\
0.4110 \\
0.405\end{array}$ & $\begin{array}{l}0.462 \\
0.456 \\
0.450 \\
0.444 \\
0.439\end{array}$ & $\begin{array}{l}0.504 \\
0.497 \\
0.491 \\
0.485 \\
0.479\end{array}$ & $\begin{array}{l}0.533 \\
0.526 \\
0.519 \\
0.513 \\
0.507\end{array}$ \\
\hline $\begin{array}{l}41 \\
42 \\
43 \\
44 \\
45\end{array}$ & $\begin{array}{l}i \\
1 \\
1 \\
1 \\
1\end{array}$ & $\begin{array}{l}0.108 \\
0.107 \\
0.105 \\
0.104 \\
0.103\end{array}$ & $\begin{array}{l}0.2,04 \\
0.2 .02 \\
0.1 .99 \\
0.197 \\
0.1 .94\end{array}$ & $\begin{array}{l}0.2 .61 \\
0.257 \\
0.2 .54 \\
0.251 \\
0.2 .48\end{array}$ & $\begin{array}{l}0.3 .09 \\
0.3 .05 \\
0.3 .01 \\
0.298 \\
0.2 .94\end{array}$ & $\begin{array}{l}0.364 \\
0.3 .59 \\
0.3 .55 \\
0.351 \\
0.3 .47\end{array}$ & $\begin{array}{l}0.4 .00 \\
0.395 \\
0.391 \\
0.386 \\
0.382\end{array}$ & $\begin{array}{l}0.433 \\
0.428 \\
0.423 \\
0.419 \\
0.414\end{array}$ & $\begin{array}{l}0.4 .73 \\
0.468 \\
0.463 \\
0.458 \\
0.453\end{array}$ & $\begin{array}{l}0.501 \\
0.495 \\
0.490 \\
0.484 \\
0.479\end{array}$ \\
\hline $\begin{array}{l}46 \\
47 \\
48 \\
49 \\
50\end{array}$ & $\begin{array}{l}1 \\
1 \\
1 \\
1\end{array}$ & $\begin{array}{l}0.102 \\
0.101 \\
0.100 \\
0.098 \\
0.097\end{array}$ & $\begin{array}{l}0.192 \\
0.190 \\
0.188 \\
0.186 \\
0.184\end{array}$ & $\begin{array}{l}0.2 .46 \\
0.2 .43 \\
0.2 .40 \\
0.238 \\
0.235\end{array}$ & $\begin{array}{l}0.2 .91 \\
0.2 .88 \\
0.285 \\
0.2 .82 \\
0.279\end{array}$ & $\begin{array}{l}0.3 .43 \\
0.3 .40 \\
0.336 \\
0.3 .33 \\
0.329\end{array}$ & $\begin{array}{l}0.378 \\
0.3744 \\
0.370 \\
0.3 .66 \\
0.3 .63\end{array}$ & $\begin{array}{l}0.410 \\
0.405 \\
0.401 \\
0.3 .97 \\
0.393\end{array}$ & $\begin{array}{l}0.448 \\
0.443 \\
0.439 \\
0.434 \\
0.430\end{array}$ & $\begin{array}{l}0.474 \\
0.469 \\
0.465 \\
0.460 \\
0.4 .56\end{array}$ \\
\hline
\end{tabular}




\begin{tabular}{|c|c|c|c|c|c|c|c|c|c|}
\hline $\begin{array}{c}\alpha(2): \\
\alpha(1) \\
n \\
\end{array}$ & $\begin{array}{l}0.50 \\
0.25\end{array}$ & $\begin{array}{l}0.20 \\
0.10\end{array}$ & $\begin{array}{l}0.10 \\
0.0 .5\end{array}$ & $\begin{array}{l}0.05 \\
0.0 .25\end{array}$ & $\begin{array}{l}0.02 \\
0.01\end{array}$ & $\begin{array}{l}0.01 \\
0.0 .05\end{array}$ & $\begin{array}{l}0.005 \\
0.00025\end{array}$ & $\begin{array}{l}0.002 \\
0.001\end{array}$ & $\begin{array}{l}0.001 \\
0.0005\end{array}$ \\
\hline $\begin{array}{l}51 \\
52 \\
53 \\
54 \\
55\end{array}$ & $\begin{array}{l}0.096 \\
0.095 \\
0.0 .95 \\
0.094 \\
0.093\end{array}$ & $\begin{array}{l}0.182 \\
0.180 \\
0.179 \\
0.177 \\
0.175\end{array}$ & $\begin{array}{l}0.233 \\
0.231 \\
0.228 \\
0.226 \\
0.224\end{array}$ & $\begin{array}{l}0.276 \\
0.274 \\
0.271 \\
0.268 \\
0.266\end{array}$ & $\begin{array}{l}0.3 .26 \\
0.3 .23 \\
0.3 .20 \\
0.317 \\
0.314\end{array}$ & $\begin{array}{l}0.359 \\
0.356 \\
0.352 \\
0.3 .49 \\
0.346\end{array}$ & $\begin{array}{l}0.390 \\
0.386 \\
0.382 \\
0.379 \\
0.375\end{array}$ & $\begin{array}{l}0.426 \\
0.422 \\
0.418 \\
0.414 \\
0.411\end{array}$ & $\begin{array}{l}0.4 .51 \\
0.447 \\
0.4 .43 \\
0.439 \\
0.435\end{array}$ \\
\hline $\begin{array}{l}56 \\
57 \\
58 \\
59 \\
60\end{array}$ & $\begin{array}{l}0.092 \\
0.091 \\
0.090 \\
0.089 \\
0.089\end{array}$ & $\begin{array}{l}0.174 \\
0.172 \\
0.171 \\
0.169 \\
0.168\end{array}$ & $\begin{array}{l}0.222 \\
0.220 \\
0.218 \\
0.216 \\
0.214\end{array}$ & $\begin{array}{l}0.264 \\
0.261 \\
0.259 \\
0.257 \\
0.255\end{array}$ & $\begin{array}{l}0.3 .11 \\
0.3 .08 \\
0.3 .06 \\
0.3 .03 \\
0.300\end{array}$ & $\begin{array}{l}0.343 \\
0.34 .40 \\
0.337 \\
0.334 \\
0.331\end{array}$ & $\begin{array}{l}0.372 \\
0.369 \\
0.366 \\
0.363 \\
0.360\end{array}$ & $\begin{array}{l}0.407 \\
0.404 \\
0.400 \\
0.397 \\
0.394\end{array}$ & $\begin{array}{l}0.432 \\
0.428 \\
0.424 \\
0.421 \\
0.418\end{array}$ \\
\hline $\begin{array}{l}61 \\
62 \\
63 \\
64 \\
65\end{array}$ & $\begin{array}{l}0.0 .88 \\
0.087 \\
0.0 .86 \\
0.086 \\
0.0 .85\end{array}$ & $\begin{array}{l}0.166 \\
0.165 \\
0.163 \\
0.162 \\
0.161\end{array}$ & $\begin{array}{l}0.213 \\
0.211 \\
0.209 \\
0.207 \\
0.206\end{array}$ & $\begin{array}{l}0.252 \\
0.250 \\
0.248 \\
0.2 .46 \\
0.244\end{array}$ & $\begin{array}{l}0.298 \\
0.296 \\
0.293 \\
0.291 \\
0.289\end{array}$ & $\begin{array}{l}0.3 .29 \\
0.326 \\
0.3 .23 \\
0.321 \\
0.318\end{array}$ & $\begin{array}{l}0.357 \\
0.354 \\
0.351 \\
0.348 \\
0.3 .46\end{array}$ & $\begin{array}{l}0.391 \\
0.388 \\
0.385 \\
0.382 \\
0.379\end{array}$ & $\begin{array}{l}0.414 \\
0.411 \\
0.408 \\
0.405 \\
0.402\end{array}$ \\
\hline $\begin{array}{l}66 \\
67 \\
68 \\
69 \\
70\end{array}$ & $\begin{array}{l}0.084 \\
0.084 \\
0.083 \\
0.082 \\
0.082\end{array}$ & $\begin{array}{l}0.160 \\
0.158 \\
0.157 \\
0.156 \\
0.155\end{array}$ & $\begin{array}{l}0.204 \\
0.2 .03 \\
0.201 \\
0.200 \\
0.198\end{array}$ & $\begin{array}{l}0.243 \\
0.241 \\
0.239 \\
0.237 \\
0.235\end{array}$ & $\begin{array}{l}0.287 \\
0.284 \\
0.282 \\
0.280 \\
0.278\end{array}$ & $\begin{array}{l}0.316 \\
0.314 \\
0.311 \\
0.3 .09 \\
0.3 .07\end{array}$ & $\begin{array}{l}0.343 \\
0.341 \\
0.338 \\
0.336 \\
0.333\end{array}$ & $\begin{array}{l}0.376 \\
0.373 \\
0.370 \\
0.368 \\
0.365\end{array}$ & $\begin{array}{l}0.399 \\
0.396 \\
0.393 \\
0.390 \\
0.388\end{array}$ \\
\hline $\begin{array}{l}71 \\
72 \\
73 \\
74 \\
75\end{array}$ & $\begin{array}{l}0.081 \\
0.081 \\
0.080 \\
0.080 \\
0.0 .79\end{array}$ & $\begin{array}{l}0.154 \\
0.153 \\
0.1 .52 \\
0.151 \\
0.150\end{array}$ & $\begin{array}{l}0.197 \\
0.195 \\
0.194 \\
0.193 \\
0.191\end{array}$ & $\begin{array}{l}0.234 \\
0.232 \\
0.230 \\
0.229 \\
0.227\end{array}$ & $\begin{array}{l}0.276 \\
0.274 \\
0.272 \\
0.271 \\
0.269\end{array}$ & $\begin{array}{l}0.3 .05 \\
0.303 \\
0.3 .01 \\
0.299 \\
0.297\end{array}$ & $\begin{array}{l}0.331 \\
0.329 \\
0.327 \\
0.324 \\
0.322\end{array}$ & $\begin{array}{l}0.363 \\
0.360 \\
0.358 \\
0.355 \\
0.353\end{array}$ & $\begin{array}{l}0.3 .85 \\
0.382 \\
0.3 .80 \\
0.377 \\
0.375\end{array}$ \\
\hline $\begin{array}{l}76 \\
77 \\
78 \\
79 \\
80\end{array}$ & $\begin{array}{l}0.078 \\
0.078 \\
0.077 \\
0.077 \\
0.076\end{array}$ & $\begin{array}{l}0.149 \\
0.148 \\
0.147 \\
0.146 \\
0.145\end{array}$ & $\begin{array}{l}0.190 \\
0.189 \\
0.188 \\
0.186 \\
0.185\end{array}$ & $\begin{array}{l}0.2226 \\
0.2224 \\
0.223 \\
0.221 \\
0.220\end{array}$ & $\begin{array}{l}0.2 .67 \\
0.265 \\
0.2 .64 \\
0.2 .62 \\
0.260\end{array}$ & $\begin{array}{l}0.295 \\
0.293 \\
0.291 \\
0.289 \\
0.287\end{array}$ & $\begin{array}{l}0.320 \\
0.318 \\
0.316 \\
0.314 \\
0.312\end{array}$ & $\begin{array}{l}0.3 .51 \\
0.349 \\
0.346 \\
0.344 \\
0.342\end{array}$ & $\begin{array}{l}0.372 \\
0.370 \\
0.368 \\
0.365 \\
0.363\end{array}$ \\
\hline $\begin{array}{l}81 \\
82 \\
83 \\
84 \\
85\end{array}$ & $\begin{array}{l}0.076 \\
0.075 \\
0.075 \\
0.074 \\
0.0 .74\end{array}$ & $\begin{array}{l}0.144 \\
0.143 \\
0.142 \\
0.141 \\
0.140\end{array}$ & $\begin{array}{l}0.184 \\
0.183 \\
0.182 \\
0.181 \\
0.180\end{array}$ & $\begin{array}{l}0.219 \\
0.217 \\
0.216 \\
0.215 \\
0.213\end{array}$ & $\begin{array}{l}0.259 \\
0.257 \\
0.255 \\
0.254 \\
0.252\end{array}$ & $\begin{array}{l}0.285 \\
0.284 \\
0.282 \\
0.280 \\
0.279\end{array}$ & $\begin{array}{l}0.3 .10 \\
0.3 .08 \\
0.3 .06 \\
0.305 \\
0.3 .03\end{array}$ & $\begin{array}{l}0.3 .40 \\
0.338 \\
0.336 \\
0.334 \\
0.332\end{array}$ & $\begin{array}{l}0.361 \\
0.359 \\
0.357 \\
0.355 \\
0.353\end{array}$ \\
\hline $\begin{array}{l}86 \\
87 \\
88 \\
89 \\
90\end{array}$ & $\begin{array}{l}0.074 \\
0.073 \\
0.073 \\
0.0772 \\
0.072\end{array}$ & $\begin{array}{l}0.139 \\
0.139 \\
0.138 \\
0.137 \\
0.136\end{array}$ & $\begin{array}{l}0.179 \\
0.177 \\
0.176 \\
0.175 \\
0.174\end{array}$ & $\begin{array}{l}0.212 \\
0.211 \\
0.210 \\
0.2 .09 \\
0.2 .07\end{array}$ & $\begin{array}{l}0.251 \\
0.250 \\
0.248 \\
0.247 \\
0.245\end{array}$ & $\begin{array}{l}0.277 \\
0.276 \\
0.274 \\
0.272 \\
0.271\end{array}$ & $\begin{array}{l}0.301 \\
0.299 \\
0.298 \\
0.296 \\
0.294\end{array}$ & $\begin{array}{l}0.330 \\
0.328 \\
0.327 \\
0.325 \\
0.323\end{array}$ & $\begin{array}{l}0.351 \\
0.349 \\
0.347 \\
0.345 \\
0.343\end{array}$ \\
\hline $\begin{array}{l}91 \\
92 \\
93 \\
94 \\
95\end{array}$ & $\begin{array}{l}0.072 \\
0.071 \\
0.0 .71 \\
0.070 \\
0.070\end{array}$ & $\begin{array}{l}0.135 \\
0.1 .35 \\
0.134 \\
0.133 \\
0.133\end{array}$ & $\begin{array}{l}0.173 \\
0.173 \\
0.172 \\
0.171 \\
0.170\end{array}$ & $\begin{array}{l}0.2 .06 \\
0.2 .05 \\
0.2 .04 \\
0.203 \\
0.202\end{array}$ & $\begin{array}{l}0.244 \\
0.243 \\
0.241 \\
0.240 \\
0.239\end{array}$ & $\begin{array}{l}0.269 \\
0.268 \\
0.267 \\
0.265 \\
0.264\end{array}$ & $\begin{array}{l}0.293 \\
0.291 \\
0.290 \\
0.288 \\
0.287\end{array}$ & $\begin{array}{l}0.3 .21 \\
0.319 \\
0.318 \\
0.316 \\
0.3114\end{array}$ & $\begin{array}{l}0.341 \\
0.339 \\
0.338 \\
0.336 \\
0.334\end{array}$ \\
\hline $\begin{array}{r}96 \\
97 \\
98 \\
99 \\
100\end{array}$ & $\begin{array}{l}0.070 \\
0.069 \\
0.069 \\
0.068 \\
0.068\end{array}$ & $\begin{array}{l}0.132 \\
0.131 \\
0.130 \\
0.130 \\
0.129\end{array}$ & $\begin{array}{l}0.169 \\
0.168 \\
0.167 \\
0.166 \\
0.165\end{array}$ & $\begin{array}{l}0.201 \\
0.200 \\
0.199 \\
0.198 \\
0.197\end{array}$ & $\begin{array}{l}0.238 \\
0.236 \\
0.235 \\
0.234 \\
0.233\end{array}$ & $\begin{array}{l}0.262 \\
0.261 \\
0.260 \\
0.258 \\
0.257\end{array}$ & $\begin{array}{l}0.285 \\
0.284 \\
0.282 \\
0.281 \\
0.279\end{array}$ & $\begin{array}{l}0.313 \\
0.311 \\
0.310 \\
0.3 .08 \\
0.3 .07\end{array}$ & $\begin{array}{l}0.332 \\
0.331 \\
0.329 \\
0.327 \\
0.326\end{array}$ \\
\hline
\end{tabular}

